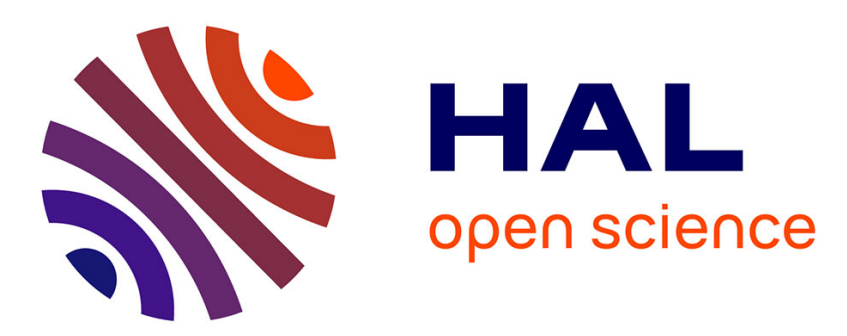

\title{
The formation of Pliocene sapropels and carbonate cycles in the Mediterranean: diagenesis, dilution, and productivity
}

\author{
Bjh van Os, Lj Lourens, Fj Hilgen, Gj de Lange, L. Beaufort
}

\section{To cite this version:}

Bjh van Os, Lj Lourens, Fj Hilgen, Gj de Lange, L. Beaufort. The formation of Pliocene sapropels and carbonate cycles in the Mediterranean: diagenesis, dilution, and productivity. Paleoceanography, 1994, 9 (4), pp.601-617. hal-01461271

\section{HAL Id: hal-01461271 \\ https://hal.science/hal-01461271}

Submitted on 3 Feb 2021

HAL is a multi-disciplinary open access archive for the deposit and dissemination of scientific research documents, whether they are published or not. The documents may come from teaching and research institutions in France or abroad, or from public or private research centers.
L'archive ouverte pluridisciplinaire HAL, est destinée au dépôt et à la diffusion de documents scientifiques de niveau recherche, publiés ou non, émanant des établissements d'enseignement et de recherche français ou étrangers, des laboratoires publics ou privés. 


\title{
The Formation of Pliocene sapropels and carbonate cycles in the Mediterranean: Diagenesis, dilution, and productivity
}

\author{
B.J.H. Van Os, ${ }^{1}$ L.J. Lourens, F.J. Hilgen, and G.J. De Lange \\ Department of Geochemistry and Geology, Institute of Earth Sciences, Utrecht, Netherlands
}

\section{Beaufort}

Laboratoire de Geologie du Quaternaire, Centre National de la Recherche Scientifique, Marseille, France

\begin{abstract}
High-resolution micropaleontological (planktonic foraminifera and calcareous nannofossils) and geochemical (stable isotopes, organic carbon, Fe, P, S, Ca, Ba, Mn, and $\mathrm{Al}$ ) records are presented for the first sapropel-containing carbonate cycle in the Pliocene of Sicily. The carbonate cycle is characterized by a gray to white to beige to white color layering typical of the marls of the Trubi formation. A faintly laminated sapropel is intercalated in the gray-colored bed of the carbonate cycle. $\mathrm{CaCO}_{3}$ content varies from $40 \%$ in the beige to $45-50 \%$ in the white layers. Lowest $\mathrm{CaCO}_{3}$ content of $25-30 \%$ is found in the gray layer and sapropel. Variations in carbonate and organic matter percentages can best be explained by changes in paleoproductivity rather than by variations in dilution and dissolution. Total productivity was highest during deposition of the gray layer and sapropel, as indicated by high organic carbon and Ba contents and high abundance of Globorotalia puncticulata. Carbonate production reached its highest values, however, during deposition of the white layers, as evidenced by enhanced abundances of planktonic foraminifera and nannofossils. The low carbonate content in the gray layer and sapropel is explained in terms of a collapse in carbonate production caused by extreme changes in the physical and biochemical properties of the water column, which in turn resulted in siliceous plankton and opportunistic foraminifers such as Globorotalia puncticulata outcompeting most calcareous organisms. The beige layer represents a lowproductivity environment similar to the present-day eastern Mediterranean basin. Several mechanisms have previously been proposed to explain variations in productivity in the eastern Mediterranean. Both sapropels and gray layers were deposited at times when perihelion occurred in northern hemisphere summer. We envisage that the increase in seasonal contrast resulting from this orbital configuration enhanced winter mixing and stabilization of the water column during summer, both leading to favorable conditions for intensification of the spring bloom. In addition, a decrease in excess evaporation, as can be deduced from the $\delta^{18} \mathrm{O}$ record, led to shoaling of the pycnocline and reduced circulation, thus enhancing the availability of nutrients in the photic zone. Finally, enhanced precipitation and associated runoff should have caused an increase in river-borne nutrients.
\end{abstract}

\section{Introduction}

The late Pleistocene sedimentary record of the eastern Mediterranean is known to contain distinct layers with elevated organic carbon content [Cita et al., 1977; Kidd et al., 1978]. These "sapropels", interbedded in hemipelagic sediments, have many characteristics (e.g., high $\mathrm{C}_{\mathrm{org}}, \mathrm{Fe}, \mathrm{S}$, and trace metals) [e.g., Calvert, 1983; Priysers et al., 1993]

'Now at Geological Survey, Haarlem, Netherlands.

Copyright 1994 by the American Geophysical Union.

Paper number 94PA00597.

0883-8305/94/94PA-00597\$10.00 in common with organic-rich black shales, such as those from the Cretaceous.

Sapropel occurrences are cyclic and correspond closely with minima in the precession index when perihelion occurred in northern hemisphere summer [Rossignol-Strick, 1983, 1985; Prell and Kutzbach, 1987; Hilgen, 1991a]. Sapropels are not only found in the upper Pleistocene, but they occur frequently and are widespread in marine sequences throughout the Mediterranean Neogene and Quatemary [c.f. Olausson, 1961; Cita et al., 1977; Shaw and Evans, 1984; Chamley et al., 1986; Howell et al., 1988; Sprovieri et al., 1986; De Visser et al., 1989; Emeis et al., 1991; Hilgen, 1991a, b; Rio et al., 1991; Thunell et al., 1991].

Much work has been done to explain the formation of the upper Pleistocene and Holocene sapropels [Rossignol-Strick 
et al., 1982; Rossignol-Strick et al., 1985; Thunell and Williams, 1989; Rohling and Gieskes, 1989; Calvert et al., 1992]. An increase in freshwater input could have resulted in the development of a low-salinity surface layer which, in turn, reduced deepwater circulation. This limited the amount of oxygen in the deeper part of the water column and could eventually have led to anoxic bottom water conditions and enhanced preservation of organic matter [Olausson, 1961; Cita et al., 1977; Nolet and Corliss, 1990]. Increased runoff from the river Nile during peaks of monsoonal precipitation on northern Africa [Rossignol-Strick et al., 1982] or from the northern borderlands of the Mediterranean [Rossignol-Strick, 1987; Rohling and Hilgen, 1991] is thought to have triggered the formation of the youngest sapropel. Evidence for a lowsalinity layer is given by $\delta^{18} \mathrm{O}$ depletions in planktonic foraminiferal shells within sapropels, which would be related to the $\delta^{18} \mathrm{O}$ signature of freshwater input [Vergnaud-Grazzini et al., 1977; Gudjonsson and van der Zwaan, 1985; Thunell and Williams, 1989; Tang and Stott, 1993]. Alternatively, an increase in nutrients may have caused enhanced marine production and associated flux of organic matter to the seafloor [Calvert, 1983; Calvert et al., 1992]. The most extreme hypothesis suggests that excess runoff and precipitation over evaporation caused a reversal of the water circulation in the (eastern) Mediterranean [Calvert, 1983; Sarmiento et al., 1988; Thunell and Williams, 1989]. Such a reversed (estuarine) circulation would act as a nutrient trap, leading to enhanced productivity and consequent sapropel formation [De Lange and Ten Haven, 1983; Thunell and Williams, 1989; Calvert et al., 1992]. Rohling and Gieskes [1989] combined decreased deepwater formation with enhanced primary production. Their scenario suggests that a decrease in excess evaporation over precipitation and runoff caused shoaling of the pycnocline (and nutricline) into the euphotic zone. This led to the developement of a distinct deep chlorophyll maximum and enhanced marine production. A consequence of this model is that the $\delta^{18} \mathrm{O}$ depletions in sapropels are related to reduced inflow of western Mediterranean water and decreased excess evaporation rather than enhanced river water input [Van $O s$ and Rohling, 1993].

Most scenarios for sapropel formation are based on upper Pleistocene sapropels but have subsequently been applied to
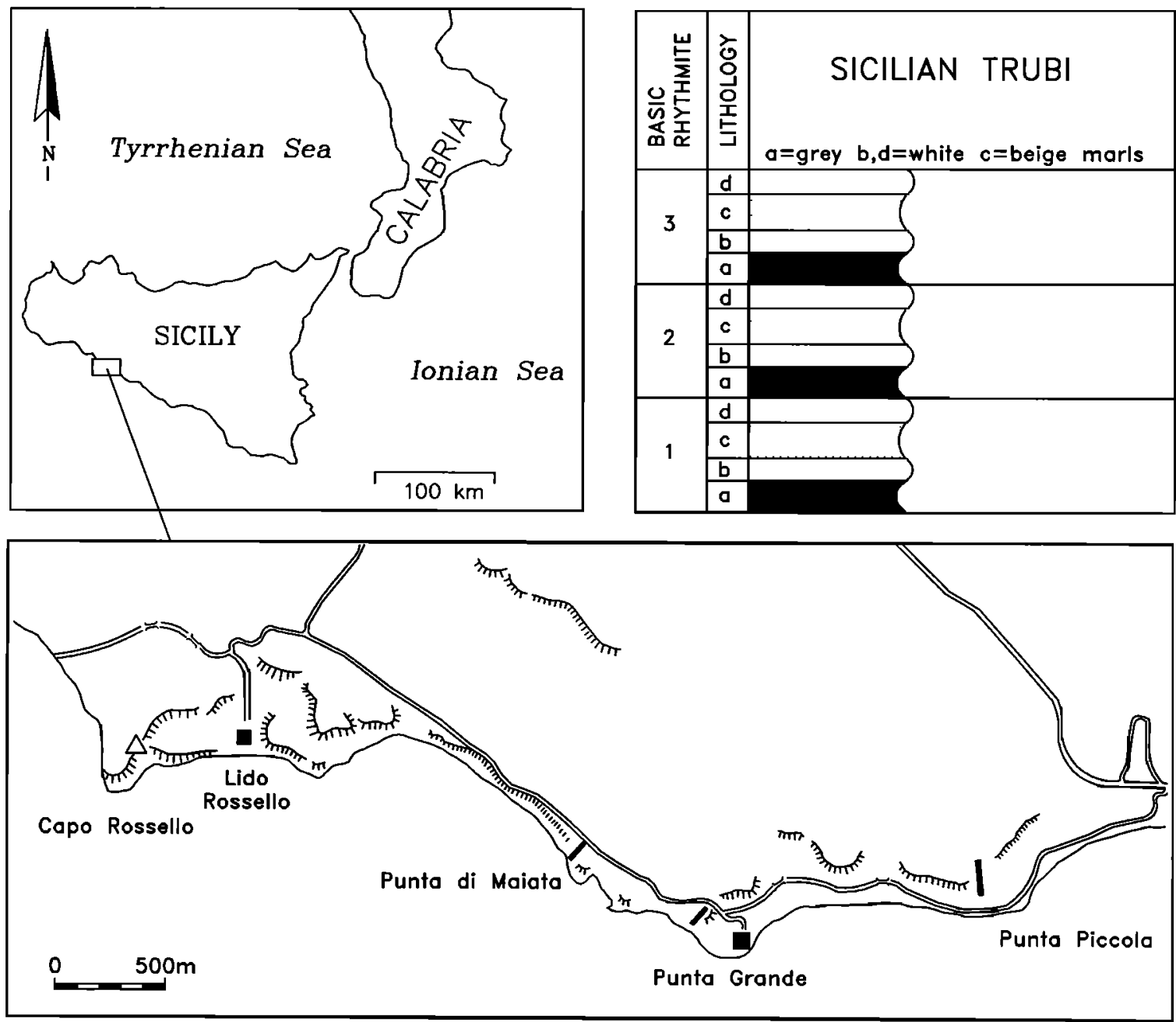

Figure 1. Location map and schematized lithology of carbonate cycle 101/102 (numbering quadruplet cycles after Hilgen [1991b]). 
lower Pleistocene and Pliocene sapropels and laminites [e.g., Gudjonsson and van der Zwaan, 1985; Sprovieri et al., 1986; Rio et al., 1991; De Visser et al., 1989; Thunell et al., 1991]. The Pliocene of the Mediterranean also contains distinctive $\mathrm{CaCO}_{3}$ cycles [Hilgen, 1987; Gudjonsson, 1987; De Visser et al., 1989; Thunell et al., 1991], which are attributed to a combination of productivity variations and dilution by enhanced terrigenous input. Thus far, the relation between sapropels and these carbonate cycles has received little attention, although sapropels often occur in certain parts of the carbonate cycles.

The main objective of this study is to elucidate the dominant processes leading to the formation of the Pliocene carbonate cycles and their intercalated sapropels. Perhaps the most suitable sediments for this task are the marly outcrops of the Pliocene Trubi and Monte Narbone formations on Sicily, which show cyclic enrichment in organic matter and carbonate. The Trubi marls display a distinct white to gray to white to beige color layering, with the gray and beige marls being less indurated and $\mathrm{CaCO}_{3}$ poor (Figure 1). In addition, the gray layers are slightly enriched in $\mathrm{C}_{\text {org }}(0.1-0.2 \%)$ [De Visser et al., 1989]. The first Pliocene, brownish-colored, laminated, sapropels start to occur in the basal part of the overlying Monte Narbone formation. These sapropels occur within or completely substitute the gray layers of the carbonate cycles [Hilgen, 1987]. We performed a high-resolution geochemical and micropaleontological study on the carbonate cycle that contains the first sapropel.

\section{Material and Methods}

\section{Geological Setting}

Samples were taken from carbonate cycle 101/102 [see Hilgen, 1991b] in the lower part of the Monte Narbone formation in the Punta Piccola section near Porto Empedocle, southern Sicily (Figure 1). The gray layer of this cycle contains a faintly laminated sapropel, which is dated astronomically at $3.07 \mathrm{Ma}$ [Hilgen, 1991b]. The sediments have been deposited at a water depth of 400-800 $\mathrm{m}$ [Brolsma, 1978] with an average sediment accumulation rate of $4.2 \mathrm{~cm}$ $\mathrm{kyr}^{-1}$ [Hilgen, 1991b]. This accumulation rate was determined by dividing the total thickness of this carbonate cycle $(=92$ $\mathrm{cm})$ by the average period of a precession cycle $( \pm 21.7 \mathrm{kyr})$.

\section{Sampling}

Considerable effort was taken to remove the weathered surface to expose the fresh sediment. After that, a 70-cm-high polygon block, weighing about $120 \mathrm{~kg}$, was carefully excavated and placed in polyethylene bags that were sealed to prevent dehydration. Back in the laboratory, the block was stored at $4^{\circ} \mathrm{C}$ to prevent further dehydration. The block was dry-sawed into 3 -cm-thick slabs perpendicular to the bedding plane. Fresh colors reappeared on the freshly sawed sides, thus facilitating the description of the lithology in detail. For the gray layer and the intercalated sapropel, fresh colors were dominantly dark green and green. The fresh colors of the beige and white layers were dark blue and light green to blue, respectively. To minimize contamination, $5 \mathrm{~mm}$ were scraped off the slab before taking the samples. Sampling was started immediately after sawing; the samples, consisting of $0.5-$ to 1-cm-thick fragments, were taken carefully with a stainless steel spatula parallel to the bedding plane. For geochemical purposes, the samples were stored at $4^{\circ} \mathrm{C}$ until analyses at the laboratory. Cores with a diameter of slightly less than $1 \mathrm{~cm}$ were drilled into the slabs at the same levels as the geochemical samples. This provided us with a fixed volume, necessary to calculate the amount of calcareous fossils per cubic centimeter of sediment.

\section{Chemical Analyses}

The samples were dried at $105^{\circ} \mathrm{C}$ for 24 hours and thoroughly ground in an agate mortar mill prior to a $\mathrm{HClO}_{4}$, $\mathrm{HNO}_{3}$, and $\mathrm{HF}$ acid digestion. The final residue was taken up in $1 \mathrm{M}$ of $\mathrm{HCl}$. The elements $\mathrm{Fe}, \mathrm{P}, \mathrm{S}, \mathrm{Ca}, \mathrm{Ba}, \mathrm{Mn}, \mathrm{Al}$, and various trace metals were measured with an inductively coupled plasma emission spectrometer (ARL 34000). The analytical precision and accuracy of the measured values were both found to be better than 3\% for all elements; this was checked by making use of an international (SO-1) and a house standard (MM-82) and by analyzing replicate samples, respectively.

\section{Organic Carbon and $\delta^{13} \mathrm{C}_{\text {org }}$}

The measurements of $\mathrm{C}_{\text {org }}$ and $\delta^{13} \mathrm{C}$ in carbonate-rich samples require that prior to the analyses, all carbonate should be removed. About $1 \mathrm{~g}$ of sample was weighed into a centrifuge tube. The carbonate was extracted by mechanical shaking with $6 \mathrm{~N} \mathrm{HCl}$ for 12 hours. Hydrochloric acid, rather than acetate acid or phosphoric acid must be used to assure complete removal of carbonate phases such as dolomite. To avoid overpressure, the centrifuge tubes were carefully degassed during the first hour of the procedure. After extraction, the samples were rinsed with demineralized water in order to remove $\mathrm{CaCl}_{2}$ and were subsequently dried. From the extracted fluids, the (dissolved) organic carbon content was determined. The results showed that the organic carbon loss due to the carbonate extraction was negligible. Organic carbon was determined volumetrically following dry oxidation with $\mathrm{CuO}$ at $900^{\circ} \mathrm{C}$ in a closed circulation system at $0.2 \mathrm{~atm}$ oxygen. The released $\mathrm{CO}_{2}$ gas was cryogenically separated from the other gases. The $\delta^{13} \mathrm{C}$ was measured with a VG SIRA 24 mass spectrometer with a precision better than $0.1 \%$. Each sample was measured in duplicate. The isotope data are reported relative to the PeeDee belemnite standard. $\mathrm{SO}_{x}$ and $\mathrm{NO}_{2}$ gases, which could interfere with the carbon content and isotopic measurements, respectively, were shown to be absent using mass spectrometer scans.

The $\delta^{13} \mathrm{C}_{\text {carb }}$ and $\delta^{18} \mathrm{O}_{\text {carb }}$

In order to remove any organic remains, about 100 specimens of Globigerinoides ruber $(10 \mathrm{mg}$ ) per sample were roasted for $30 \mathrm{~min}$ at $470^{\circ}$ under a helium flow. After that, the samples were transferred into glass reaction tubes that were evacuated for 14 hours. This was followed by 6 hours of reaction with $100 \%$ phosphoric acid at $25.0^{\circ} \mathrm{C}$ under high vacuum. The released $\mathrm{CO}_{2}$ was cryogenically separated from the other gases and measured on a VG SIRA 24 mass spectrometer. Data are reported as per mil relative to the PDB standard. Replicate analyses and repetitive analyses of the laboratory standard showed a standard deviation of $<0.1 \%$ for both $\delta^{13} \mathrm{C}$ and $\delta^{18} \mathrm{O}$. 


\section{Calcareous and Silicious Fossils}

Foraminiferal counts were made on splits (using an Otto microsplitter) from the $125-$ to $595-\mu \mathrm{m}$ and $65-$ to $125-\mu \mathrm{m}$ fractions, and 200-500 specimens of the 125- to $595-\mu \mathrm{m}$ fraction were hand-picked, mounted on Chapman slides, identified, and counted.

Calcareous nannofossil counts were made from slides prepared through a settling method which allowed the estimation of the number of specimens per gram sediment. For each sample, a number of view fields were scanned until a total of 300 specimens were encountered.

Total calcareous fossil content (shells per cubic centimeter) was determined for four different size fractions: (1) 125-595 $\mu \mathrm{m}$ (planktonic foraminifera), (2) 65-125 $\mu \mathrm{m}$ (planktonic foraminifera), (3) 10-50 $\mu \mathrm{m}$ (calcareous dinoflagellates), and (4) $<10 \mu \mathrm{m}$ (nannofossils). Dinoflagellate and nannofossil counts were made on every second sample.

Opal concentrations were determined in the sediment according to the method of Demaster [1981]. The precision of this method is better than $10 \%$ for values larger than $1 \%$ of opal.

\section{Results}

\section{Geochemical Analyses}

$\mathrm{CaCO}_{3}$ concentrations are enhanced in the white layers, have intermediate values in the beige layers, and are lowest in the gray layer and intercalated sapropel (Figures 2 and 3). Because of the closed sum effect, $\mathrm{CaCO}_{3}$ varies inversely with the other major phases in the sediment, such as aluminosilicates. Phosphorous concentrations resemble the pattern as displayed in the $\mathrm{CaCO}_{3}$ record. Organic carbon concentrations are elevated in the gray layer and intercalated sapropel, are low in the beige layers, and have intermediate values in the white layers (Figure 3).

Iron and sulphur are both enriched in the gray layer. To correct for terrigenous iron, the $\mathrm{Fe} / \mathrm{Al}$ ratio was computed, which shows a good correlation $\left(R^{2}=0.86\right)$ with sulphur. The molar Fe/S ratio of about 2 suggests that most iron and sulphur in the sapropel are present in the form of pyrite. Although organic carbon and sulphur are both enriched in the gray layer, no good correlation is found between organic carbon and sulphur.

Barium is enriched in the gray layer (Figure 3) and correlates well with $\mathrm{C}_{\text {org }}\left(\mathrm{R}^{2}=0.89\right)$. In the sapropel, a small decrease in $\mathrm{Ba}$ is observed where $\mathrm{Mn}$ (Figure 4) displays a very prominent peak.

The elements $\mathrm{Ti}, \mathrm{Al}, \mathrm{Zr}$, and $\mathrm{Cr}$, which are contributed mainly by the terrigenous fraction, are enriched in the gray and beige layers and are depleted in the white layers (Figure 5).

\section{Stable Isotopes}

The $\delta^{18} \mathrm{O}$ record of Globigerinoides ruber shows a "bellshaped" profile, which is slightly asymmetric with respect to the lithology. Lowest $\delta^{18} \mathrm{O}$ values $(-2.5 \%)$ are reached at the base of the sapropel, while enrichments in $\delta^{18} \mathrm{O}$ are found in the white layer $(-0.5 \%)$ below the gray layer and in the beige layer $(+0.5 \%$ o $)$ (Figure 3$)$.

The $\delta^{13} \mathrm{C}_{\mathrm{G} \text {. ruber }}$ shows a stepwise decrease at the white-gray

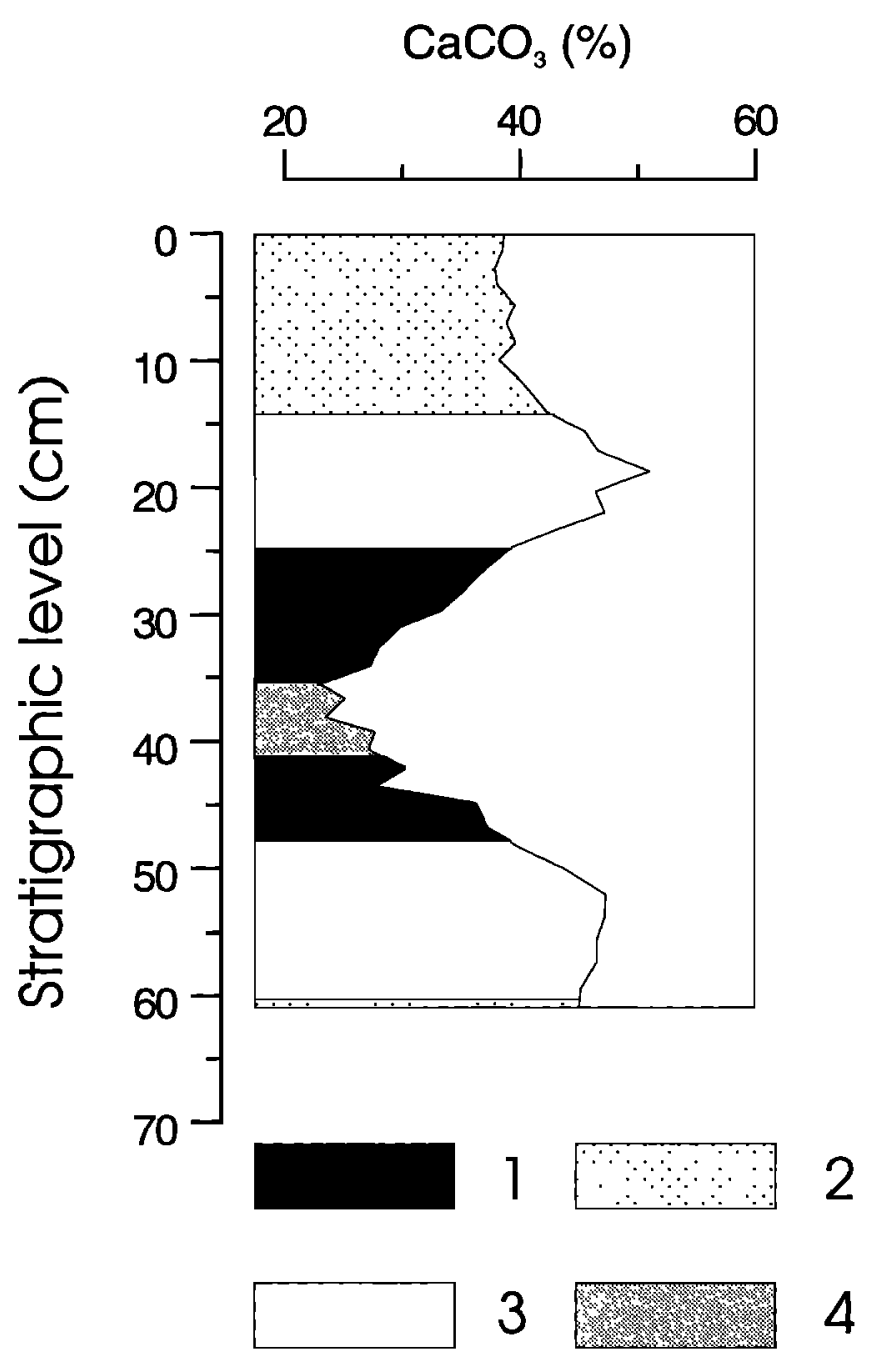

Figure 2. Stratigraphic column of carbonate cycle 101/102: $1=$ gray layer; 2 = beige layer; $3=$ white layer; and $4=$ sapropel. Note that lithology shows close resemblance with the $\mathrm{CaCO}_{3}$ content.

boundary, reaching its lowest $\delta^{13} \mathrm{C}$ value $(-0.25 \%$ o $)$ in the lower part of sapropel. The largest enrichment in ${ }^{13} \mathrm{C}\left(\delta^{13} \mathrm{C} \approx\right.$ $1.2 \%$ ) is found in the white layer that precedes the gray layer (Figure 3).

The $\delta^{13} \mathrm{C}_{\text {org }}$ values vary between -22.5 and $-24.5 \%$ (Figure 3). The largest enrichment in ${ }^{13} \mathrm{C}_{\text {org }}$ is recorded in the gray layer and intercalated sapropel, whereas the most depleted values occur in the white layers. Intermediate values $\left(\delta^{13} \mathrm{C}_{\mathrm{org}} \approx-23 \%\right.$ ) are recorded in the beige layer.

\section{Paleontological Data}

Sixteen planktonic foraminiferal categories were counted and their distributions are shown in Figure 6a. Taxonomy of planktonic foraminifers is after Lourens et al. [1992]. The most conspicuous feature is the elevated percentages of Globorotalia puncticulata in the gray layer and intercalated sapropel.

The calcareous nannofossil assemblages have low diversity. The preservation is moderate to poor (i.e., less than $10 \%$ of 


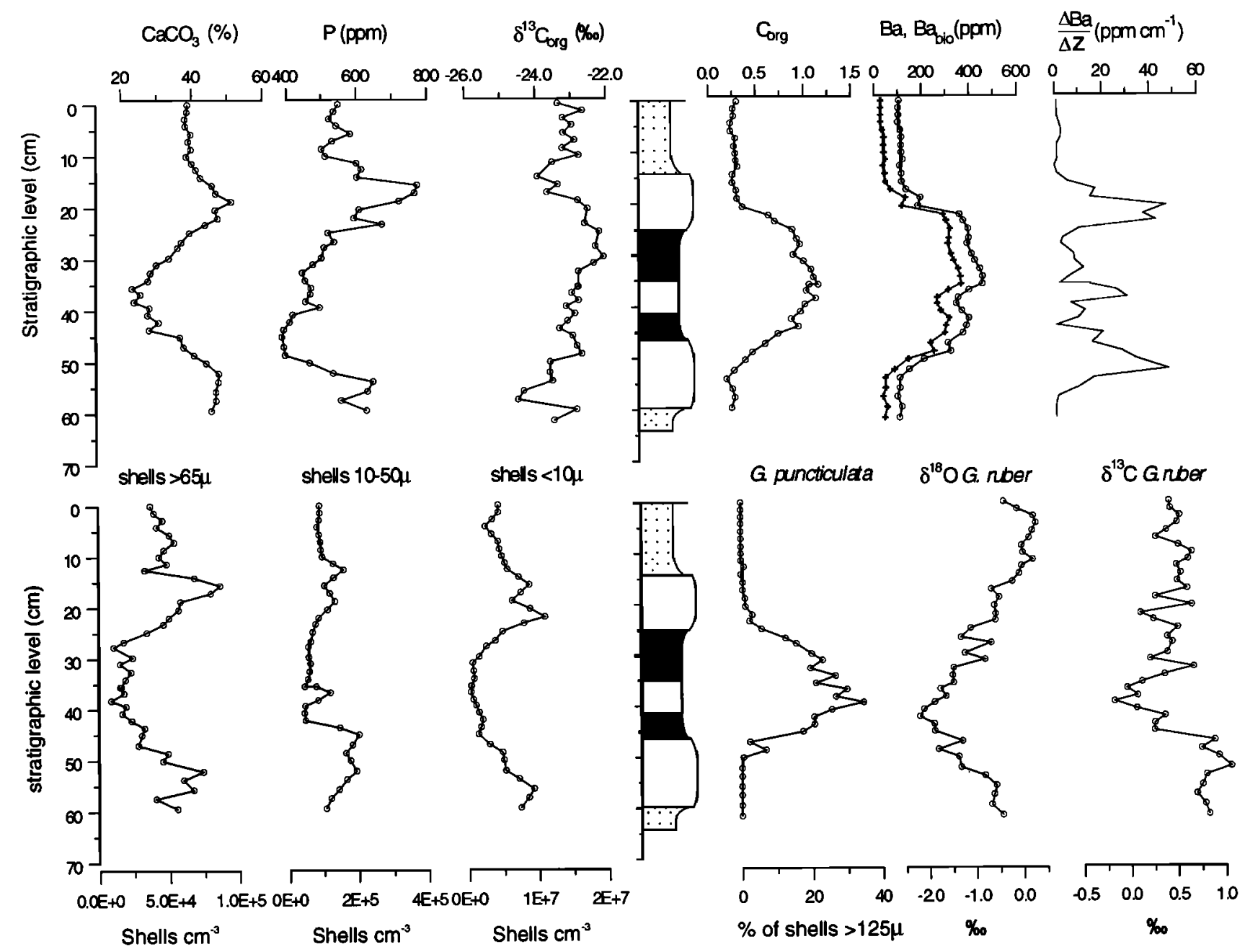

Figure 3. Variations of $\mathrm{CaCO}_{3}, \mathrm{P}, \delta^{13} \mathrm{C}_{\text {org }}, \mathrm{C}_{\text {org }}, \mathrm{Ba}$, biological bound $\mathrm{Ba}, \mathrm{Ba}$ derivative, shell content $>65$ $\mu \mathrm{m}$, shell content $10-50 \mu \mathrm{m}$, shell content $<10 \mu \mathrm{m}$ in species per cubic centimeter, percentage $G$. puncticulata of shell fraction $125-595 \mu \mathrm{m}$, and $\delta^{18} \mathrm{O}$ and $\delta^{13} \mathrm{C}$ of G.ruber, versus stratigraphic level.

shell ratio index

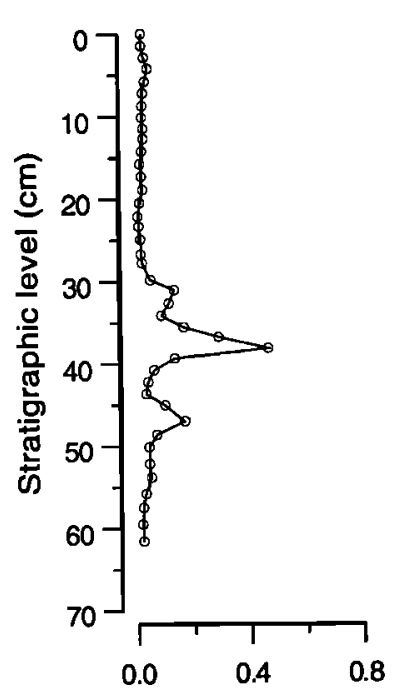

$\mathrm{Mn}$

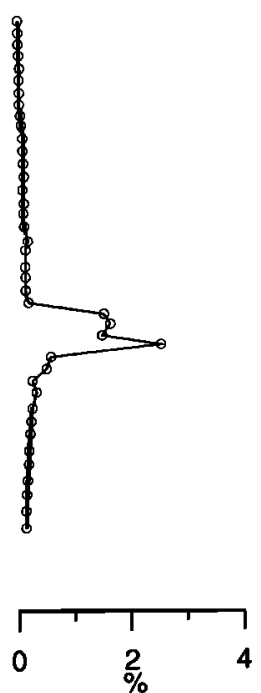

Discoaster

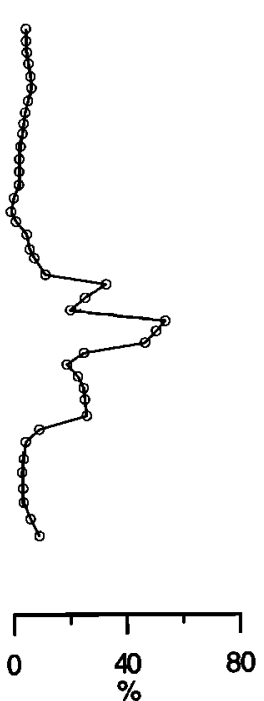

$\mathrm{Fe}^{*}$

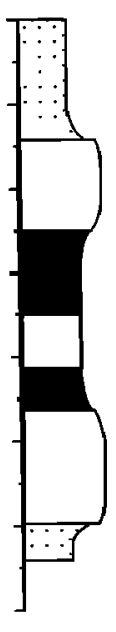

Figure 4. Comparison of shell fraction ratio (shell fraction $>10 \mu \mathrm{m} /$ shell fraction $<10 \mu \mathrm{m}$ ), percentages of discoasters, $\mathrm{Mn},(\mathrm{Fe} / \mathrm{Al}) \mathbf{x}$ (average $\mathrm{Al}$ ), and $\mathrm{S}$ variations, versus stratigraphic level. 

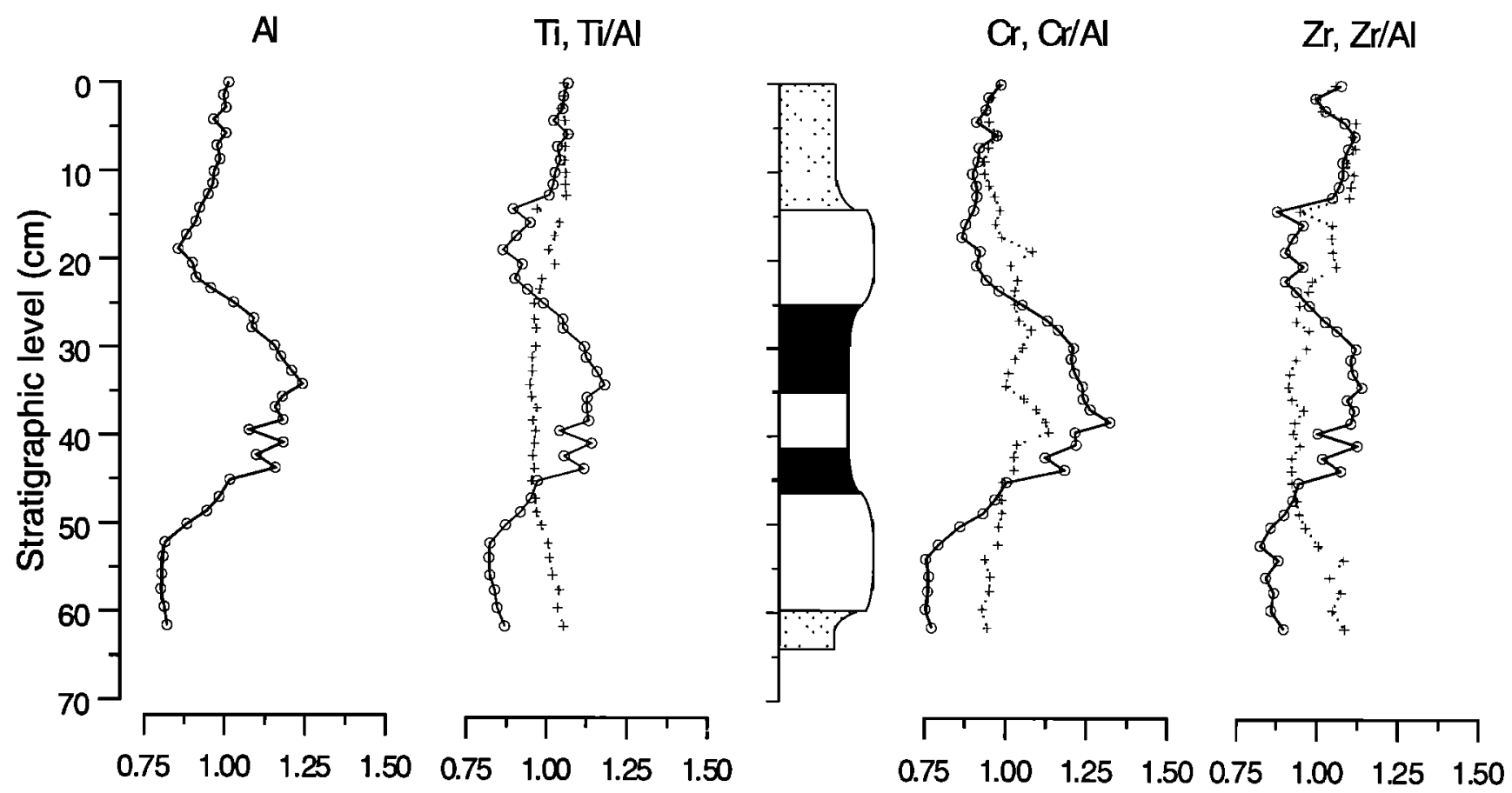

Normalized concentrations

Figure 5. Normalized (divided by their average values) concentrations of $\mathrm{Al}, \mathrm{Ti}, \mathrm{Cr}$, and $\mathrm{Zr}$ (circles) and normalized $\mathrm{Ti} / \mathrm{Al}, \mathrm{Cr} / \mathrm{Al}$, and $\mathrm{Zr} / \mathrm{Al}$ ratios (pluses), versus stratigraphic level.

the discoasters are well preserved). The assemblages are dominated by Reticulofenestra minutula and Coccolithus pelagicus in the gray and beige layers, by discoasters and Calcidiscus pelagicus in the white layers, and by discoasters in the sapropel (Figure 6b). This pattern is similar to that found by Thunell et al. [1991] for the Trubi marls. At the level of the sapropel, the abundance of coccoliths decreases dramatically while the number of discoasters remains almost constant, resulting in the relative dominance of this group at this level (Figures 4 and $6 \mathrm{~b}$ ).

The patterns displayed in the records of the total number of calcareous fossils of the different size fractions are nearly identical to that displayed in the $\mathrm{CaCO}_{3}$ record but resemble even more the $\mathrm{P}$ record (Figure 3 ). In addition, most species display high abundances in the white layers and very low abundances in the gray layer. Increased calcareous fossil contents are recorded in the white layers, they are intermediate in the beige layer and low in the gray layer and intercalated sapropel. Despite the lower calcareous fossil content in the planktonic foraminiferal association $>125 \mu \mathrm{m}$, the sapropel and gray layers are characterized by an increase in Globorotalia puncticulata (Figures 3 and 6a), which shows a remarkable correlation with the organic carbon $\left(R^{2}=0.83\right)$ and barium content $\left(R^{2}=0.67\right)$.

\section{Discussion}

\section{Formation of Carbonate Cycles and Sapropels}

The most conspicuous feature of the carbonate cycle is the strong variation in carbonate and organic matter content.
Dilution and productivity have been proposed to explain similar variations in Pliocene carbonate cycles and sapropels of southern Italy [De Visser et al., 1989; Howell et al., 1990; Thunell et al., 1991; Van der Weijden, 1993]. In addition, Sprovieri et al. [1986] suggested that diagenesis could be responsible for the variation in carbonate content. In the next section, we will discuss each process separately, so as to assess its potential importance in determining the $\mathrm{CaCO}_{3}$ and $\mathrm{C}_{\text {org }}$ content of these sediments.

\section{Diagenesis}

Evidence for dissolution comes from the abundance pattern of discoasters. Discoasters are adapted to an oligotrophic environment [Chepstow-Lusty et al., 1989]. Apart from this paleoenvironmental significance, discoasters are thought to be more resistant to dissolution than small placoliths (Reticulofenestra minutula), and Calcidiscus pelagicus. Discoaster abundance will therefore be relatively higher after dissolution [Lohmann and Carlson, 1981]. Enhanced dissolution occurred in the sapropel and at the boundaries of the gray layer. The relative enhanced abundance of discoasters in the sapropel closely matches the $\mathrm{Mn}$ concentrations (Figure 4).

To assess significance and timing of diagenesis we will discuss the possible effects during the successive diagenetic stages: (1) deposition, (2) early diagenesis, (3) diagenesis after burial and (4) weathering.

Deposition. Dissolution of $\mathrm{CaCO}_{3}$ is often reported to occur in shelf sediments, even as the overlying seawater is supersaturated with respect to calcite [Morse and MacKenzie, 
Planktonic foramiferal associations (\%)
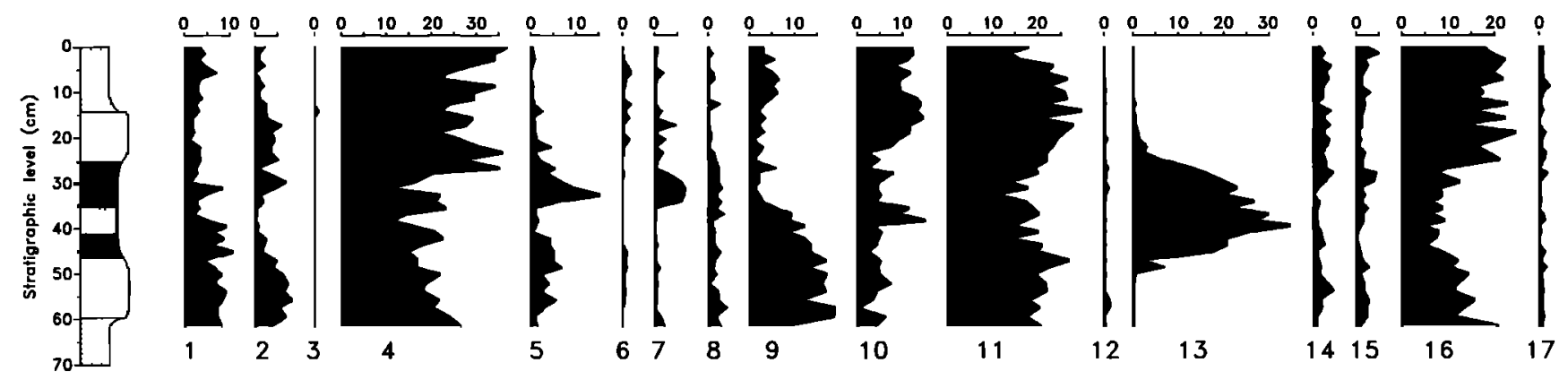

Planktonic foraminiferal associations (shells $/ \mathrm{cm}^{3}$ )
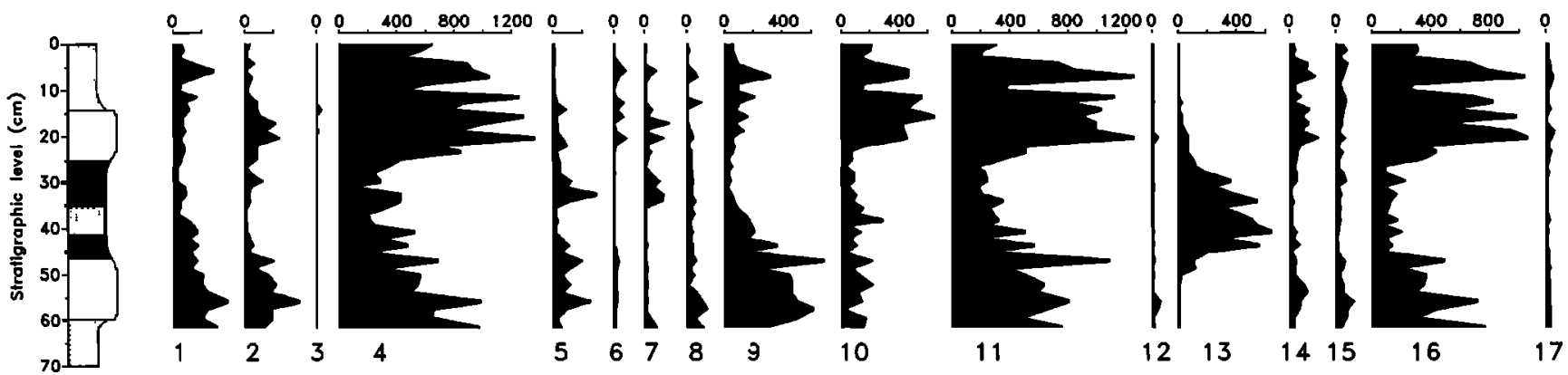

Figure 6a. Abundances and accumulation rates of planktonic foraminifera versus depth: $1=G$. ruber; 2 $=G$. sacculifer; $3=$ Sph. sp.; $4=G$. apertura; $5=$ G. obliquus; $6=G$. siphonifera; $7=G$. bulloides; $8=$ G. bulloides (intermediate); $9=G$. falconensis; $10=$ G. bulliodes (juvenile); $11=$ Neogloboquadrina sp. (dextral); $12=$ Neogloboquadrina sp. (sinistral); $13=$ G. puncticulata; $14=$ o. universa; $15=T$. quinqueloba; $16=G$. glutinata $; 17=$ species indeterminable.

\section{Calcareous nannofossils (\%)}
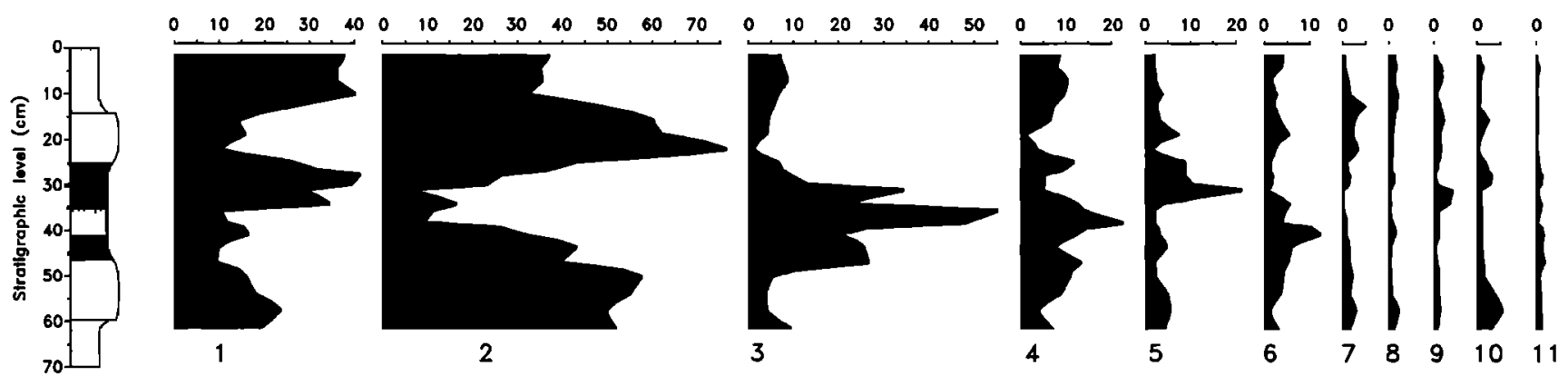

Calcareous nannofossils (coccoliths *10 $10^{6} / \mathrm{cm}^{3}$ )
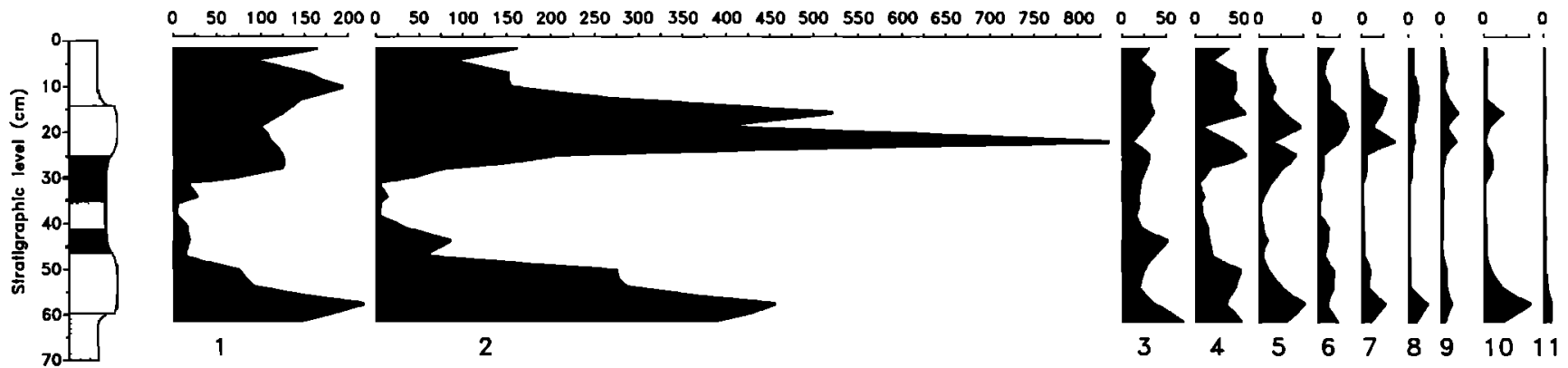

Figure 6b. Abundances and accumulation rates of calcareous nannofossils versus depth: $1=C$. pelagicus; $2=R$. minutula $; 3=$ discoasters; $4=C$. leptoporus; $5=C$. macintyrei; $6=H$. carteri; $7=H$. sellii; $8=U$. sibogae; $9=P$. spp.; $10=$ sp. indet.; $11=$ reworking. 
1990]. The presumed depth of accumulation was $400-800 \mathrm{~m}$, that is, well above the lysocline (present-day equals $3000 \mathrm{~m}$ ) and beyond the reach of corrosive bottom waters that could dissolve $\mathrm{CaCO}_{3}$. In addition, the modern eastern Mediterranean water column is entirely saturated with respect to calcite.

During deposition, $\mathrm{CaCO}_{3}$ dissolution can occur during oxic decomposition of organic matter at the sediment-water interface following the reactions [Emerson and Archer, 1990]

$$
\begin{aligned}
& \mathrm{CH}_{2} \mathrm{O}+\mathrm{O}_{2} \rightarrow \mathrm{CO}_{2}+\mathrm{H}_{2} \mathrm{O} \\
& \mathrm{CO}_{2}+\mathrm{CaCO}_{3}+\mathrm{H}_{2} \mathrm{O} \rightleftharpoons 2 \mathrm{HCO}_{3}^{-}+\mathrm{Ca}^{2+}
\end{aligned}
$$

In such a system, build-up of $\mathrm{HCO}_{3}$, which would slow down dissolution, is prevented by high benthic activity. Throughout the studied interval, the total amount of benthic foraminifers in the 125 to $595-\mu \mathrm{m}$ fraction was low $\left(\approx 125 \mathrm{shells} / \mathrm{cm}^{3}\right)$ and remained almost constant. This suggests that the system was not sufticiently closed to prevent mixing with supersaturated bottom waters. However, the occurrence of pyrite in the gray layer and intercalated sapropel indicates that anoxic conditions prevailed in the subsurface sediment during deposition. In the very early stages of sulphate reduction, a decrease in $\mathrm{pH}$ might be expected, which will result in undersaturation with respect to most carbonate minerals [Canfield and Raiswell, 1991]. Pervasive sulphate-reducing conditions, however, will produce alkalinity that will enhance the preservation of $\mathrm{CaCO}_{3}$ [Morse and MacKenzie, 1990].

If dissolution was the only cause to explain the decrease in $\mathrm{CaCO}_{3}$ from $55 \mathrm{wt} \%$ (or $55 \mathrm{~g}$ ) in the white layer to $21 \mathrm{wt} \%$ (or $12 \mathrm{~g}$ ) within the gray layer and sapropel (thus assuming a constant terrigenous flux of $45 \mathrm{~g}$ ), this would suggest that $78 \%\left(43 \mathrm{~g}\right.$ ) of $\mathrm{CaCO}_{3}$ dissolved at the sediment-water interface. To dissolve this amount of $\mathrm{CaCO}_{3}$, about $12 / 100$ (molecular weight $\mathrm{C}_{\text {org }} / \mathrm{CaCO}_{3}$ ) x $43 \mathrm{~g}=5.16 \mathrm{gr}$ (or $5.16 \mathrm{wt}$ $\%) \mathrm{C}_{\text {org }}$ has to be decomposed. Decomposition of such (unrealistically) large amounts of $\mathrm{C}_{\text {org }}$ would rapidly exhaust oxygen in the pore water and subsequently anoxic conditions at the sediment-water interface. The occurrence of benthic foraminifera, however, contrasts this scenario.

The fact that the percentages of discoasters did not increase in the low-carbonate beige-colored layer of the carbonate cycle but only in the gray layer and sapropel may suggest that dissolution might have occurred above a certain threshold value of $\mathrm{C}_{\text {org. }}$. The relative abundances of discoasters increased between 48 and $30 \mathrm{~cm}$ during which $\mathrm{C}_{\text {org }}$ values vary between 0.4 and $1.2 \%$. This would imply that dissolution already started to occur for $C_{\text {org }}$ percentages larger than $0.4 \%$. Consequently, we would have expected to find enhanced percentages of discoasters within the $50-$ to $20-\mathrm{cm}$ interval. The relative abundances of discoasters, however, already decreased at $30 \mathrm{~cm}$. It therefore seems unlikely that the observed dissolution pattern is related to a certain threshold value. In addition, the pattern displayed in the discoaster abundances does not show a clear correlation with the organic carbon content in this interval. Moreover, this dissolution index shows a good relation with the lithological boundaries and faintly laminated sapropel in this carbonate cycle rather than with $\mathrm{C}_{\text {org. }}$. We conclude that organic carbon decomposition did not induce carbonate undersaturation in the sediment, which implies that the decrease of $\mathrm{CaCO}_{3}$ in the gray layer cannot result from dissolution during deposition.

Early diagenesis. After deposition of the gray layer, sulphate reduction probably ceased because of the diminished supply of reactive organic carbon. This is also indicated by the low pyrite content in the surrounding white and beige layers. In this situation, replenishment of oxygen in the sediment may occur, which can lead to the development of a progressive oxidation front. As a result, oxygen penetrating into the sediment will react with reduced iron and manganese, causing the formation of metal-rich layers above the previously anoxic sediment [Pruysers et al., 1993]. However, progradation of the front will be seriously hampered by the high organic carbon and pyrite contents that were previously formed in the gray layer. Only after oxidation of most sulphides and organic matter will the front progress. Therefore it is extremely unlikely that the Mn-rich layer, found in the center of the gray layer and in which organic matter and sulphide are still abundant, would be formed during this stage in diagenesis. Oxidation of organic matter in this stage can also result in the dissolution of $\mathrm{CaCO}_{3}$ following the reactions (1) and (2). However, the $C_{\text {org }}$ profile does not indicate that penetration of an oxidation front has occurred. Such an oxidation front would have resulted in a stepwise increase of the organic matter concentration and the formation of iron and manganese enrichments above the organic-rich layers [e.g., Pruysers et al., 1993; Thomson ef al. 1993]. In addition, in view of the relatively low reactivity of organic matter after deposition, these reactions may be assumed to take place in a closed system. As a consequence, of the re-equilibration of reaction (2), $\mathrm{CaCO}_{3}$ dissolution will slow down. Instead of making a number of assumptions in an effort to calculate the resulting organic matter decomposition to the observed decrease in $\mathrm{CaCO}_{3}$, we prefer to refer to the results of a natural decomposition experiment. In the Madeira Abyssal Plain, the oxic decomposition of about $0.6 \%$ organic matter has resulted in a $3 \%$ decrease in $\mathrm{CaCO}_{3}$ content [Thomson et al., 1993]. Extrapolation to the carbonate cycles under investigation would require decomposition of more than $9 \%$ organic carbon to explain the $34 \%$ decrease in $\mathrm{CaCO}_{3}$, assuming a constant terrigenous flux.

Carbonate dissolution due to acid production during the oxidation of pyrite [Stumm and Morgan, 1981] in the gray layer probably did not occur, because pyrite is still abundant and products of pyrite oxidation (gypsum and iron (hydr)oxides) are not found. Therefore carbonate dissolution during the oxic decomposition of organic matter and sulphides seems unlikely, and the observed decrease in carbonate cannot be explained by early diagenesis.

Diagenesis after burial. Diagenetic $\mathrm{CaCO}_{3}$ dissolution and precipitation caused by interaction with large volumes of formation water could have occurred after burial. The burial depth of these relatively young sediments most probably did not exceed $300 \mathrm{~m}$, which virtually excludes large-scale diagenetic processes. Furthermore, exchanges with formation and meteoric water would be marked by significant shifts in $\delta^{18} \mathrm{O}$ and $\delta^{13} \mathrm{C}$ of the carbonate due to recrystallization or dolomitization. Although a shift to more negative $\delta^{18} \mathrm{O}$ values is observed in the sapropel, these shifts are small compared with reported values of calcite recrystallized during burial diagenesis [cf. Morse and MacKenzie, 1990]. Moreover, 
careful examination of all shell fractions did not show any signs of diagenetic alteration. Therefore the effect of dissolution during burial is thought to be insignificant.

Weathering. Subaerial weathering can contribute significantly to the lithological appearance and chemical alteration of the sediments [Van Os et al., 1993]. In the carbonate cycle $106 / 107$ in the Punta Piccola section in particular, organic carbon, sulphur, and $\delta^{13} \mathrm{C}_{\text {org }}$ show significant changes at $\mathrm{Mn}$ - and Fe-enriched levels [Van Os et al., 1993]. This is thought to be caused by infiltration of acidic, meteoric water subsequently followed by transport of water along highly conductive planes. Oxidation of pyrite and organic matter could have caused the dissolution of $\mathrm{CaCO}_{3}$ (reaction (2)) and other constituents. As mentioned before, the oxidation of pyrite produces acidity and could dissolve large amounts of carbonate. In this carbonate cycle, a manganeserich layer is also found in the sapropel, parallel to the bedding, plane indicating that this kind of dissolution might have occurred in this carbonate cycle as well. A ratio of greater than $10-\mu \mathrm{m}$ versus less than $10-\mu \mathrm{m}$ shell fractions (shell ratio index) (Figure 4) resembles the pattern as displayed in the percentages of discoasters and indicates that the small fraction was easier dissolved at the boundary of the gray layer and in the sapropel than the coarser fractions. Although one might assume that the largest shells would be affected more easily by dissolution, we suggest that the larger shells could still be identified and counted, whereas the smaller shells could not be recognized anymore. As an alternative explanation, it can be hypothesised that because of subaerial wheathering, the small fraction was easier winnowed by meteoric water transport than that of the coarse fraction. Nevertheless, organic matter and sulphur do not significantly decrease at the Mn- enrichment, suggesting that they were not affected by weathering. In addition, $\delta^{13} \mathrm{C}_{\text {org }}$ shows no variation within the Mn-enriched layer.

Summarizing, minor dissolution has occurred during weathering in the Mn-enriched layer. This dissolution process, however, cannot explain the total variations in $\mathrm{CaCO}_{3}$ and $\mathrm{C}_{\text {org }}$ content in this carbonate cycle, because (1) the shell ratio index and relative abundance of discoasters did not increase during deposition of the beige layer, which is also characterized by low $\mathrm{CaCO}_{3}$ contents and low absolute number of calcareous fossils and (2) the variation in the $\mathrm{CaCO}_{3}$ content does not correspond well with a decrease in discoasters: the most rapid increase in the relative abundance of discoasters is accompanied by only a small decrease in $\mathrm{CaCO}_{3}$ content.

\section{Dilution and Productivity}

Dilution is a process commonly used to explain variations in $\mathrm{CaCO}_{3}$ in sediments deposited above the carbonate compensation depth. Geochemical studies of the Trubi and Monte Narbone formations, as well as the younger sediments of the Vrica section, suggest that dilution with terrestrial clastics played an important role during the formation of the carbonate cycles and sapropels [De Visser et al., 1989; Howell et al., 1990; Thunell et al., 1991; Van der Weijden. 1993]. De Visser et al. [1989] used dilution to explain the low carbonate content in the gray marls of the Trubi formation. In addition, they attributed the white and beige marl beds to periods of high and low carbonate production, respectively.
It is difficult to distinguish between the effect of dilution and carbonate production, since lower carbonate production and increasing terrigenous accumulation have similar effects on lithology. The two most extreme cases of the effect of dilution versus the effect of carbonate production on the accumulations rates is demonstrated in Figure 7 by assuming a constant carbonate input or constant terrigenous input, respectively.

For the determination of accumulation rates, the terrigenous fraction $\left(\mathrm{f}_{\text {ter }}\right)$ was estimated as $100-\mathrm{CaCO}_{3}(\%)-\mathrm{C}_{\text {org }}(\%)$; the carbonate fraction $\left(\mathrm{f}_{\text {carb }}\right)$ was calculated from the $\mathrm{Ca}$ concentration, assuming $\mathrm{CaCO}_{3}$ is the only carbonate mineral present and neglecting the contribution of aluminosilicatebound $\mathrm{Ca}$. Accumulation rates are in $\mathrm{g} \mathrm{cm}^{-2} \mathrm{kyr}^{-1}$, assuming that constant carbonate production and an average sedimentation rate of $4.2 \mathrm{~cm} \mathrm{kyr}^{-1}$ [Hilgen, 1991b] can be calculated for different constituents $[\mathrm{M}]$ by

$$
[M]_{\text {acc }}=\frac{\left(\frac{f_{M}}{f_{c a r b}}\right)}{\operatorname{avg}\left(1+\frac{f_{\text {terr }}}{f_{\text {carb }}}+\frac{f_{\text {org }}}{f_{\text {carb }}}\right)} \times 4.2 \times \mathrm{p}
$$

where $\rho$ is bulk density in grams per cubic centimeter $(\sim 1.5$ $\mathrm{g} \mathrm{cm}^{-3}$ ). The accumulation rate of constituents [M] during constant terrigenous accumulation can be calculated by

$$
[M]_{\text {acc }}=\frac{\left(\frac{f_{M}}{f_{\text {terr }}}\right)}{\operatorname{avg}\left(1+\frac{f_{\text {carb }}}{f_{\text {terr }}}+\frac{f_{\text {org }}}{f_{\text {terr }}}\right)} \times 4.2 \times \mathrm{p}
$$

Dilution. The major result of assuming a constant carbonate accumulation rate is that the terrigenous accumulation rate was highest during deposition of the gray layer and sapropel, and the lowest during deposition of the white layers (Figure 7). Such enhanced terrigenous accumulation in the gray layer would certainly be marked by variations in mineralogy and grain size. Grain size measurements of sediments from the Trubi formation show that a higher proportion of relatively large particles was deposited in the beige beds compared with the white or gray beds [De Visser et al., 1989]. Furthermore, the gray layers were characterized by a small range in particle size, suggesting a riverine source. De Visser et al. [1989] therefore concluded that during deposition of the gray layer, the carbonate signal was diluted with river-derived terrigenous material. Although we did not carry out grain size analysis on our samples, the Ti/Al, $\mathrm{Zr} / \mathrm{Al}$, and $\mathrm{Cr} / \mathrm{Al}$ ratios can also be used as indicators for grain size variations. The nearly constant but slightly lower $\mathrm{Ti} / \mathrm{Al}, \mathrm{Zr} / \mathrm{Al}$, and $\mathrm{Cr} / \mathrm{Al}$ ratios in the gray layer and sapropel compared with the surrounding white and beige layers (Figure 5) are consis- 

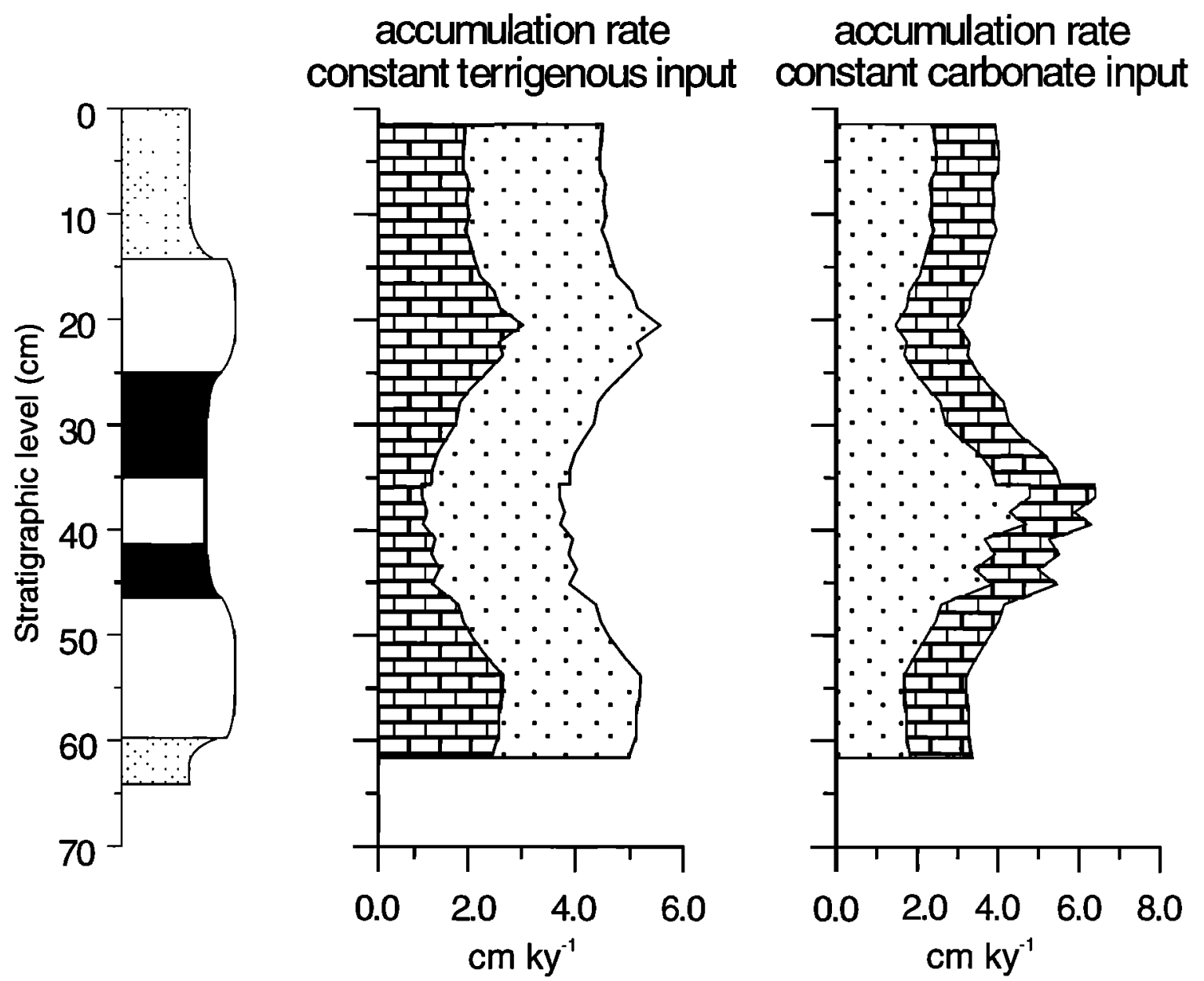

Figure 7. Cummulative accumulation rate diagram of carbonate accumulation rates (blocks) and terrigenous accummulation rates (dots), assuming a constant terrigenous input (left) and constant carbonate input (right).

tent with the grain size variations observed by De Visser et al. [1989].

Although the inferred variations in grain size may give an indication of the provenance of terrigenous material, they give no definite answer to the question of whether the amount of terrigenous material increased or decreased during deposition of the gray layer. A more direct indication of the amount of terrigenous input comes from the $\delta^{13} \mathrm{C}$ of organic matter. Sackett [1964] and Jasper and Gagosian [1990] showed that $\delta^{13} \mathrm{C}_{\text {org }}$ can be used as an indicator of changes in the provenance of organic matter due to the different $\delta^{13} \mathrm{C}$ values for terrestrial and marine organic matter. Assuming a constant carbonate accumulation rate, the $\mathrm{C}_{\text {org }}$ accumulation rate gradually increases from $0.15 \mathrm{~g} \mathrm{~cm}^{-2} \mathrm{kyr}^{-1}$ in the beige layer to $0.60 \mathrm{~g} \mathrm{~cm}^{-2} \mathrm{kyr}^{-1}$ in the sapropel (Figure 8) and is closely correlated with the terrigenous flux. If this increase in organic carbon were mainly caused by enhanced terrigenous organic matter supply, one would expect a lighter $\delta^{13} \mathrm{C}_{\text {org }}$ value in the sapropel. However, the enhanced $\delta^{13} C_{\text {org }}$ values $(\approx-22.5 \%$ ) (Figure 3 ) in the gray layer and intercalated sapropel are typical values for organic matter derived from marine plankton. In most marine settings, organic carbon from terrestrial sources has isotopically lighter values. Therefore an increased influx of terrestrial organic carbon in the gray layer and intercalated sapropel might not be expected.

Consequently, the low carbonate content and high organic carbon content in the gray layer and sapropel cannot adequately be explained by enhanced terrigenous input. Thus variations in carbonate content must be explained by changes in productivity (Figure 7).

Productivity. The major result of assuming a constant terrigenous accumulation rate is that the carbonate accumulation rate was highest during deposition of the white layers, intermediate in the beige layer, and lowest in the gray layer and intercalated sapropel (Figure 7). Based on increased planktonic abundances and high carbonate content in the white beds, Thunell et al. [1991] postulated that the white carbonate-rich beds of the Trubi formation were formed during periods of enhanced paleoproductivity. In the sediments under investigation, this considerable increase in carbonate and calcareous fossils of the various size fractions is also observed (Figure 6). In this section we test the hypothesis that these white layers reflect periods of highest paleoproductivity.

A direct method for estimating paleoproductivity is to calculate the organic carbon flux to the sediment from the $\mathrm{C}_{\text {org }}$ 

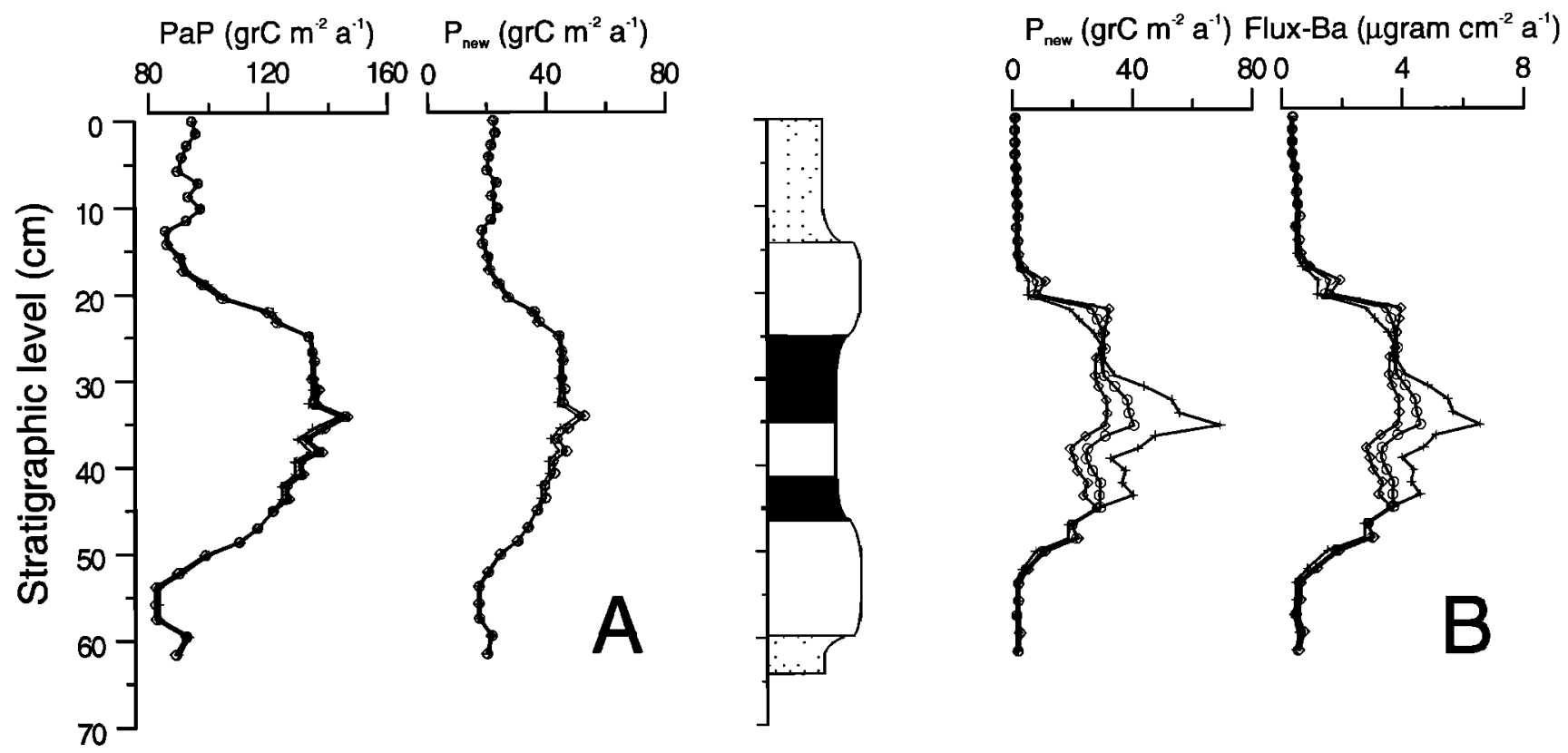

Figure 8. (a) Paleoproductivity ( $\mathrm{PaP}$ ) and new paleoproduction estimates (Pnew) computed from the (marine) organic carbon content (equations (6) and (7)) assuming constant terrigenous input (pluses), contant carbonate input (diamonds), and constant sedimentation rate (circles). (b) $\mathrm{Ba}_{\mathrm{tio}}$ flux and $\mathrm{P}_{\mathrm{new}}$ computed from the $\mathrm{Ba}_{\mathrm{blo}}$ content (equations (8)-(11)) assuming constant terrigenous input (diamonds), constant carbonate input (pluses) and constant sedimentation rate (circles).

content. To calculate the marine fraction of total $\mathrm{C}_{\text {org }}$ we used the method of Calder and Parker [1968] and Jasper and Gagosian [1990]:

$$
\mathrm{MC}_{\text {org }}=\mathrm{C}_{\text {org }} \times\left[\left(\delta^{13} \mathrm{C}_{\mathrm{i}}-\delta^{13} \mathrm{C}_{\mathrm{T}}\right) /\left(\delta^{13} \mathrm{C}_{\mathrm{M}}-\delta^{13} \mathrm{C}_{\mathrm{T}}\right)\right]
$$

where $\delta^{13} \mathrm{C}_{1}=\delta^{13} \mathrm{C}_{\text {org }}$ of a given sample, $\delta^{13} \mathrm{C}_{\mathrm{T}}=\delta^{13} \mathrm{C}_{\text {orp }}$ of the terrigenous end-member equals $-26.6 \pm 0.7 \%$, and $\delta^{3} \mathrm{C}_{\mathrm{T}}$ $=\delta^{13} \mathrm{C}_{\text {org }}$ of the marine end-member equals $-20.6 \pm 2.2 \%$. Export productivity is commonly used for describing the amount of organic matter that leaves the photic zone [Mïller and Suess, 1979; Berger et al., 1989; Sarnthein et al., 1988, 1992]. We have computed the paleoproductivity (P) and new paleoproductivity $\left(\mathrm{P}_{\text {new }}\right)$ according to the empirical transfer equation for Pleistocene paleoproductivity from Sarnthein et al. [1992]:

$$
\begin{aligned}
& \mathrm{P}=61.390 \mathrm{C}_{\mathrm{A}}^{0.250} \mathrm{~S}_{\mathrm{B}-\mathrm{C}^{-0.049} \mathrm{z}^{0.150}} \\
& \mathrm{P}_{\text {new }}=9.354 \mathrm{C}_{\mathrm{A}}^{0.493} \mathrm{~S}_{\mathrm{B}-\mathrm{C}^{-0.105} \mathrm{z}^{0.300}}
\end{aligned}
$$

where $\mathrm{C}_{\mathrm{A}}$ is the weight percent of the marine organic matter, $S_{B-C}$ equals the sedimentation rate, and $z$ is $600 \mathrm{~m}$. We assumed that the (organic) carbon free sedimentation rate $\left(\mathrm{S}_{\mathrm{B}}\right.$ c) nearly eaquals the bulk sedimentation rate $\left(S_{B}\right)$. The $P$ estimate varies from $\pm 140 \mathrm{gC} \mathrm{m}^{-2} \mathrm{yr}^{-1}$ in the sapropel to \pm 90 $\mathrm{gC} \mathrm{m}^{-2} \mathrm{yr}^{-1}$ in the beige layer (Figure 8 ). The $\mathrm{P}$ values in the beige layer are in very good agreement with the paleoproductivity estimates derived from the modern western Mediterranean, which vary between 87.7 and $106 \mathrm{gC} \mathrm{m}^{-2} \mathrm{yr}^{-1}$ (see Morel and André [1991, and references therein]). Moreover, this value is close to the mean annual fixation rate of the world ocean of about 111 or $75 \mathrm{gC} \mathrm{m}^{-2} \mathrm{yr}^{-1}$ when using the total carbon fluxes proposed by Bolin [1983] or Berger et al. [1987]. From this viewpoint the $P$ estimates of the beige layers of the carbonate cycle turns out to be close to the "mean" world ocean. The paleoproductivity estimates in the gray layer and intercalated sapropel are higher than those estimated in the high-productivity conditions in the northern part of the western Mediterranean and in the Alboran Sea (see Morel and André [1991]). Moreover, these estimates are comparable to present-day productivity values recorded along upwelling regions such as the Arabian Sea [Murray and Prell, 1992] and the Peruvian coast [Fleming, 1957; KoblentsMishke et al., 1970; Berger et al., 1987; Schrader, 1992].

To eliminate the effects of decomposition or enhanced preservation of organic matter on the paleoproductivity estimates, one may use a tracer of paleoproductivity that is not affected by diagenesis, such as barium [Goldberg and Arrhenius, 1958; Boström et al., 1973; Church. 1979; Brumsack, 1986; Calvert, 1983; Schmitz, 1987; Klinkhammer and Lambert, 1989; Dymond et al., 1992]. Barium is a good indicator for export production of marine organic matter, because it is removed by organic particles from the photic zone [Bishop, 1989; Dehairs et al., 1987]. While organic matter may be decomposed in the water column or in the sediment, the barium signal will be preserved in the sediment. Diagenetic remobilization of barium is reported to occur under pervasive anoxic conditions [Brumsack, 1986; Van Os et al., 1991]. Although sulphate-reducing conditions were developed in the sediment studied here during deposition of the sapropel, as suggested by the presence of ironsulphides, the $\mathrm{Ba}$ distribution does not indicate significant remobilization. The small decrease of $\mathrm{Ba}$ found at the $\mathrm{Mn}$ - 
enriched zone does, however, indicale that some remobilization of Ba has occurred during weathering. Dymond et al. [1992] developed a method to estimate the organic matter flux to the sediment from the Ba content. We have applied this method by computing the biological Ba fraction according to Dymond et al. [1992]:

$$
\mathrm{Ba}_{(\text {bio })}=\mathrm{Ba}_{(\text {total })}-\left(\mathrm{Al} \times \mathrm{Ba} / \mathrm{Al}_{\text {alumunosilicale }}\right)
$$

The $\mathrm{Ba} / \mathrm{Al}_{\text {aluminositicate }}$ was calculated as follows: First, we calculated the $\mathrm{Ba} / \mathrm{Al}_{\text {aluminosstcak }}$ value of the samples of the beige layer by assuming that the measured Ba concentrations in this part of the record are primarily related to the terrigenous fraction. This results in a $\mathrm{Ba} / \mathrm{Al}_{\text {aluminosilicak }}$ value of 0.0028 . However, according to Dehairs et al. [1987], at least $30 \%$ of the Barium measured in the marine sediments of the modern Mediterranean are from biologic origin. This results in a $\mathrm{Ba} / \mathrm{Al}_{\text {aluminosileate }}$ value of 0.0019 . Dehairs et al. [1987] argued that the most important source for terrigenous $\mathrm{Ba}$ in the Mediterranean is dust from the Sahara, which has an average $\mathrm{Ba} / \mathrm{Al}$ value of 0.02 . A comparison between this value and the $\mathrm{Ba} / \mathrm{Al}_{\text {alummosilcate }}$ obtained from the beige layer indicates that about $90 \%$ of the terrigenous barium derived from the Sahara desorbs when the dust particles enter seawater, which is not unrealistic (see also Dehairs el al. [1987]). The $\mathrm{Ba} / \mathrm{Al}_{\text {alumnosicate }}$ ratio $(0.0019)$ used in this study is much lower than the value used by Dymond et al. [1992]. This can be explained by higher volcanic contributions in the Pacific and Atlantic Oceans from mid-ocean ridges. Dymond et al. [1992] used the following equations to calculate the $\mathrm{Ba}_{\mathrm{bto}}$ flux to the sediment:

$$
\mathrm{Ba}_{\mathrm{b} \mathrm{o}_{\mathrm{o}}} \text { flux }=\left(\mathrm{Ba}_{\mathrm{b10-acc}}\right) /(0.209 \log (\mathrm{MAR})-0.213)
$$

where MAR is the mass accumulation rate $\left(\mu \mathrm{g} \mathrm{cm}^{-2} \mathrm{yr}^{-1}\right)$ and $\mathrm{Ba}_{\mathrm{b}_{10-\mathrm{acc}}}$ is the biological $\mathrm{Ba}\left(\mathrm{Ba}_{\left(\mathrm{bbo}_{0}\right)}\right)$ accumulation rate. The percentage of barium preservation is about $60 \%$ throughout the studied interval, notwithstanding the different MAR scenarios. Based on equation (9) we computed the mean rates of new production using the algorithm of Dymiond et al. [1992]:

$$
\mathrm{P}_{\text {new }}=\left[\left(\mathrm{Ba}_{\mathrm{blo}} \text { flux } 0.171 \mathrm{Ba}^{2.218} \mathrm{z}^{0.476-0.00478 \mathrm{Ba}}\right) / 2056\right]^{1.504}(10)
$$

Dissolved barium contents of $75 \mathrm{nmol} \mathrm{kg}{ }^{-1}$ were taken from the modern eastern Mediterranean [Lea and Boyle, 1990]. The $P_{\text {new }}$ derived by this is in good agreement with the $P_{\text {new }}$ values derived directly from the organic matter content (Figure 8). Evidently, paleoproductivity seems to have been highest during deposition of the gray layer; it was significantly lower in the white layers and lowest in the beige layer.

\section{Cause of Productivity Changes}

The increase in paleoproductivity as calculated from the amount of $\mathrm{C}_{\text {org }}$ is accompanied by elevated percentages of the planktonic foraminiferal species Globorotalia puncticulata. This species disappeared from the Mediterranean and North Atlantic at about 2.41 Ma [Zachariasse et al., 1990; Zijderveld et al., 1991]. The successor of this species, Globorotalia inflata, proliferates in temperate regions during winter [e.g.,
Tolderlund and Bé, 1971] when deep stirring cools and eutrophicates the mixed layer or during periods of coastal upwelling. Coastal upwelling in temperate regions occurs for instance along the Iberian coast where Globorotalia inflata reaches elevated percentages during the summer upwelling season. Within the upwelling center, however, Globigerina bulloides and Turborotalita quinqueloba are more abundant (compare plankton haul data of $B \dot{e}$ and Hamlin [1967] with coastal upwelling conditions of Wooster et al. [1976]). We assume that Globorotalia puncticulata had similar habitat characteristics as Globorotalia inflata, although some evidence exists that this species thrived at slightly higher temperatures [Kennett and Srinivasan, 1983; Loubere and Moss, 1986].

Within the modern Mediterranean, Globorotalia inflata occurs most frequently in the moderately cool western basin and has an abundance maximum in the Alboran Sea [Thunell, 1978]. Unfortunately, studies of seasonal variations in the abundance patterns of planktonic foraminifers in the Mediterranean area are scarce. Nevertheless, some preliminary results from the Ligurian Sea (northern part of the western Mediterranean Sea) show that Globorotalia inflata thrives in this region during February to May [Glaçon et al., 1971]. The major oceanic feature in this region is the existence of a permanent cyclonic circulation of the surface waters. In winter, intense vertical convection occurs within the central zone, and cooled, dense, surface waters mix with the underlying Levantine Intermediate Water [Medoc Group, 1970; Killworth, 1976; Gascard, 1978], resulting in nutrient enrichment of the mixed layer. Remote sensing of algal pigments in the upper ocean layer [Morel and André, 1991] demonstrate that during winter the short residence time of algae in the photic zone prevents efficient uptake of nutrients and biomass development. However, these nutrients are utilized after the surface layer becomes more stable, because it keeps phytoplankton in the euphotic zone [Gran, 1931] (see also Mann and Lazier [1991 and references therein]). This causes an algal bloom which starts in mid-April and reaches its maximum in early May. It seems plausible, therefore, to conclude that the high abundances of Globorotalia inflata are linked to such a spring bloom. In addition, the Alboran Sea is also an area of high primary production (see VergnaudGrazzini and Pierre [1991] for an overview). The distribution of algae in this area is directly linked to the circulation of the Atlantic waters entering the Mediterranean Sea [Morel and André, 1991] which results in the development of a frontal system along the Almeria-Oran transect in the east and an upwelling system on the southwest Spanish coast near Malaga. Taken together, this suggests that Globorotalia inflata thrives in relatively high primary productivity regions in the western Mediterranean. The habitat conditions for Globorotalia inflata are optimal during stabilization of the surface layer, shortly after deep winter mixing and subsequent eutrophication of the mixed layer.

Although at present such processes remain largerly limited to the western Mediterranean, it may be speculated that these processes developed periodically in the eastern basin at times of sapropel formation. Sapropels were deposited at times when the precession index reached minimum values, indicating that perihelion occurred in the northern hemisphere 
summer [Rossignol-Strick, 1985; Prell and Kutzbach, 1987; Hilgen, 1991a]. This orbital configuration implies that winter insolation decreases, whereas summer insolation increases, resulting in a larger seasonal contrast. This increase in seasonal contrast may have caused intensified winter mixing and concomittant nutrification of the euphotic layer and an enhanced stabilization of the water column during summer, both resulting in enhanced primary productivity conditions along the northern margin of the entire Mediterranean (see also Lourens et al. [1992]).

The increase in summer insolation may also have resulted in an increase in freshwater discharge via the river Nile by an intensification of the Indian Ocean's summer monsoon [Rossignol-Strick, 1983] or by enhanced precipitation in the northern borderlands of the eastern Mediterranean [RossignolStrick, 1987] (see Rohling and Hilgen [1991] for a review). Such an increase in runoff is thought to have enriched the basin with more nutrients, resulting in higher primary production. At the present time, however, river nutrients are quite efficiently removed by phytoplankton growth in estuaries; as soon as sufficient light is available (when the suspended load of the river settles out), diatoms grow rapidly and strip the nutrients from the water. Although such an increase in marine productivity will be found near the river mouth, this mechanism cannot be totally excluded from explaining the observed higher marine productivity conditions in the gray layer and sapropel. Evidence in the marine record of increased river discharge at times of sapropel formation comes from significant shifts to lighter surface water $\delta^{18} \mathrm{O}$ values [Vergnaud-Grazzini et al., 1977; Williams et al., 1978; Thunell and Williams, 1989]. Similar shifts are also recorded in the gray layers and sapropels of the Pliocene carbonate cycles [Gudjonsson and van der Zwaan, 1985; this paper] (see Figure 3 ). The relationship between sapropel formation and enhanced runofl has been convincingly demonstrated for the youngest, Holocene sapropel $S_{1}[$ Rossignol-Strick et al., 1982; Rossignol-Strick, 1985] and $S_{5}$, which formed within isotopical stage 5e [Wijmstra et al., 1990; McKenzie, 1993]. These oxygen isotope depletions are not caused primarily by an increase in the freshwater input but may be the result of a reduction in the excess of evaporation over precipitation and runoff, and variations in volume of exchange through the Strait of Sicily together with changes in the isotopic composition of the inflow [Van Os and Rohling, 1993]. The balance between excess precipitation, runoff, and evaporation is determined by variations in local humidity, which is linked to the activity of Mediterranean depressions [Rohling and Hilgen, 1991].

The reduced excess evaporation should have led to shoaling of the pycnocline into or within the euphotic layer leading to the development or intensification of the deep chlorophyll maximum and enhanced primary production [Rohling and Gieskes, 1989; Castradori, 1993]. Besides its generally shallower position, erosion of the pycnocline is facilitated by severe winter mixing, both resulting in enhanced eutrophication of the mixed layer. When the surface layer becomes more stable, the enriched nutrient concentration will be trapped, resulting in a productivity increase. The pycnocline shoaling is possibly recorded by the $\delta^{13} \mathrm{C}$ of Globigerinoides ruber, which shows a shift to lower values in the white beds with a distinct minimum in the sapropel (Figure 3). A decrease in $\delta^{13} \mathrm{C}$ values is generally attributed to upwelling of cold nutrient-rich water depleted in ${ }^{13} \mathrm{C}$ [Curry et al., 1992]. In the present case, this depletion in $\delta^{13} \mathrm{C}$ can be caused by the gradual shoaling of the pycnocline and associated nutricline into the photic zone, enhancing the influence of $\delta^{13} \mathrm{C}$-depleted, and more nutrient-rich, intermediate water. Note that these $\delta^{13} \mathrm{C}$ shifts are common in upper Pleistocene sapropels [Fontugne and Calvert, 1992] as well as in Pliocene sapropels [Gudjonsson and van der Zwaan, 1985]. Previous studies attributed $\delta^{13} \mathrm{C}$ shifts in sapropels to enhanced freshwater supply with a $\delta^{13} \mathrm{C}$ of about -10\%o [Gudjonsson and van der Zwaan, 1985; Fontugne and Calvert, 1992]. However, the contribution in $\mathrm{HCO}_{3}{ }^{\circ}$, and $\delta^{13} \mathrm{C}$ of the Nile and other rivers is probably insignificant when compared with the western Mediterranean inflow of $\mathrm{HCO}_{3}{ }^{-}$as has been shown in a similar fashion for $\delta^{18} \mathrm{O}$ by Van $O s$ and Rohling [1993].

The carbonate content seems to correspond to the derivative of the $\mathrm{Ba}$ and $\mathrm{C}_{\text {org }}$ content (Figure 3): the largest changes in productivity coincide with the highest carbonate contents. This shift from intermediate productivity in the white layers to high productivity in the gray layers is marked by very rapid decreases in the amount of calcareous fossils except for Globorotalia puncticulata (Figure 3). The abundances of nannofossils, especially Reticulofenestra minitula and Calcidiscus pelagicus, which are highest in the white layers, dramatically decrease from a white to a gray layer. Although some of this decrease may be due to preferential dissolution of these species, the decrease coincides with the high productivity values. The enhanced abundances in the white layers correspond perfectly with an increasing (from white to gray) or decreasing (from gray to white) productivity. Apparently, carbonate production decreased while total production was significantly enhanced. Modern upwelling areas give an indication of a possible explanation of this phenomenon. For example, results of the multitracers project [c.f. Welling et al. 1992; Ortiz and Mix, 1992] suggest that upwelling is characterized by enhanced primary production and a change to dominance of opportunistic species, such as diatoms. Furthermore, high primary production is mostly preceded by enhanced carbonate production, which significantly decreases during periods of high primary production [e.g., Shimmield et al., 1990; Ortiz and Mix, 1992; Hay and Brock, 1992]. Consequently, as fertility increases, siliceous plankton and opportunistic calcareous planktonic species, such as Globorotalia puncticulata, Globorotalia inflata and Globigerina bulloides, replace the nonopportunistic calcareous plankton taxa, and $\mathrm{C}_{\text {org }}$ flux increases. In combination with concomitant changes in the physical and biochemical properties of the water column, this eventually results in a collapse of the carbonate production. Diatoms dominate the newly upwelled waters, whereas coccoliths and other microflagellates may bloom in mature stratified upwelled waters depleted in nutrients [Mitchell-Innes and Winter, 1987]. This pattern is also recognized in global maps of paleoproductivity, where high-productivity areas are characterized by high silica and organic carbon contents that are surrounded by carbonate-rich sediments in lower-productivity zones [Bishop, 1989]. 
If we apply this scenario to the carbonate cycles of the Monte Narbonne formation, then the beige layers represent periods of low paleoproductivity, although supply of windblown material from African sources may have played an additional role [De Visser et al., 1989] in lowering the $\mathrm{CaCO}_{3}$ content by dilution. During deposition of the white layers, productivity values increased to those responsible for carbonate-enriched deposits centered around modern upwelling areas. Successively, paleoproductivity (and nutrient concentrations) reached maximum values in the gray layer and sapropel, with values similar to modern high productivity areas. At these times, sediment accumulation was characterized by enhanced input of (marine) organic matter and decreased carbonate accumulation rates caused by the replacement of calcareous organisms by the more opportunistic siliceous species (Figure 7).

Opal derived from siliceous organisms is not found in the gray layer and intercalated sapropel. This is similar to observations in eastern Mediterranean late Pleistocene sapropels that are absolutely devoid of opal [Erba, 1991; E. Erba and H. Schrader, personal communication, 1993] except for sapropels found in the eastern part of the eastern Mediterranean [Schrader and Matherne, 1981]. An explanation for this is that under oxic or intermittent oxic/anoxic sedimentation, opal will rapidly dissolve because of undersaturation of silica in the water column and pore water [Hurd, 1973].

High productivity associaled with opal accumulation can be inferred, however, from studies of upper Pliocene diatomaceous laminites in the Bianco section (Calabria, southern Italy) [Rio et al., 1991] and in the Heraklion area on Crete (Greece) [Jonkers, 1984]. Field observations in the Bianco area indicate that these layers enriched in biogenic silica are intercalated in the gray layers of carbonate cycles. In addition, diatomaceous layers on Crete were deposited at the same time as gray layers and sapropels on Sicily [Hilgen, 1987].

\section{Conclusions}

The formation of sapropels and carbonate cycles in the late Pleistocene and Pliocene have a common cause that is primarily controlled by variations in productivity. Changes in carbonate content are also mainly due to changes in productivity. During high productivity, carbonate production collapsed because of faster growth of more opportunistic organisms, which probably were also more tolerant toward rapidly changing physical and biochemical conditions. Enhanced terrigenous input may have occurred during deposition of the beige, low productivity layers.

Acknowledgments. We are grateful to A. Antonarakou for assisting with the planktonic foraminiferal analyses and G. Versteegh for analyzing the dinoflagellates. G. Ittmann and G. J. van het Veld are thanked for preparing the samples. We also thank A. van Dijk, G. Nobbe, P. Anten for assisting with the geochemical analyses. J. Middelburg, W. J. Zachariasse, E. J. Rohling, G. Nolet, K. Miller, and two anonymous reviewers are thanked for their critical comments, which have improved the paper significantly. This study was partly funded by the Netherlands Organization for Scientific Research (NWO grant to L. J. Lourens).

\section{References}

Bé, A. W. H., and W. H. Hamlin, Ecology of recent planktonic foraminifera, 3, Distribution in the North Atlantic during the summer of 1962, Micropaleontology, 13, 87-106, 1967.

Berger, W. H., K. Fisher, C. Lai, and G. Wu, Ocean productivity and organic flux, 1, Overview and maps of primary production and export production, Ref. 87-30, 67 pp., Scripps Inst. of Oceanogr., Univ, of Calif., La Jolla, 1987.

Berger, W. H., V. S. Smetaceck, and G. Wefer, Ocean productivity - An overview, in Productivity of the Ocean: Present and Past, edited by W. H. Berger, V. S. Smetaceck, and G. Wefer, Dahlem Workshop Rep. Life Sci. Res. Rep., 44, 1-34, 1989.

Bishop, J. K. B., The barite-opal-organic carbon association in oceanic particulate matter, Nature, 332, 341-343, 1989.

Bolin, B., The carbon cycle, in The Major Biogeochemical Cycles and Their Interactions, SCOPE 22, edited by B. Bolin and R. Cook, pp. 41-65, John Wiley, New York, 1983.

Boström, K., O. Joensuu, C. Moore, B. Boström, M. Dalziel, and A. Horowitz, Geochemistry of barium in pelagic sediments, Lithos, 6, 159-174, 1973.

Brolsma, M. J., Quantitative foraminiferal analysis and environmental interpretation of the Pliocene and topmost Miocene on the south coast of Sicily, Utrecht Micropaleontol. Bull., 18, 1159, 1978.

Brumsack, J. H., The inorganic geochemistry of Cretaceous black shales (DSDP leg 41) in comparison to modern upwelling sediments from the Gulf of California, in North Atlantic Paleoceanography, Geol. Soc. Spec. Publ. London, 21, 447462, 1986.

Calder, J. A., and P. L. Parker, Stable carbon isotope ratios as indices of petrochemical pollution of aquatic systems, Environ. Sci. Technol., 2, 535-539, 1968.

Calvert, S. E., Geochemistry of Pleislocene sapropels and associated sediments from the eastern Mediterianean, Oceanol. Acta, 6, 255-267, 1983.

Calvert, S. E., B. Nielsen, and M. R. Fontugne, Evidence from nitrogen isotope ratios for enhanced productivity during formation of eastem Mediterranean sapropels, Nature, 359, 223-225, 1992.

Canfield, D. E., and R. Raiswell, Carbonate precipitation and dissolution: Its relevance to fossil preservation, in Taphonomy; Releasing the Data Locked in the Fossil Record, Topics in Geobiology Vol., 9, ediled by P. A. Allison, and D. E. G. Briggs, pp. 441-453, Plenum, New York, 1991.

Castradori, D., Calcareous nannofossils and the origin of eastern Mediterranean sapropels, Paleoceanography, 8, 459-471, 1993.

Chamley, H., J. E. Meulenkamp, W. J. Zachariasse, and G. J. van der Zwaan, Middle to late Miocene marine ecostratigraphy: Clay minerals, planktonic foraminifera and stable isotopes from Sicily, Oceanol. Acta, 9, 227-238, 1986.

Chepstow-Lusty, A., A. Backman, and N. J. Shackleton, Comparison of upper Pliocene discoaster abundance variations from North Atlantic sites 552, 607, 658, 659, and 662: Further evidence for marine plankton responding to orbital forcing, Proc. Ocean. Drill. Program Sci. Results, 108, 121-141, 1989.

Church, T. M., Marine barite, in Marine Minerals, edited by R. G. Burns, Short Course Notes Mineral. Soc. Am., 6, 175-209, 1979.

Cita, M. B., C. Vergnaud-grazzini, C. Robert, H. Chamley, N. Ciaranfi, and S. d'Onofrio, Paleoclimatic record of a long deep sea core from the eastern Mediterranean, Quat. Res., 8, 205235, 1977.

Curry, W. B., D. R. Ostermann, M. V. S. Guptha, and V. Ittekot, Foraminiferal production and monsoonal upwelling in the 
Arabian Sea: Evidence from sediment traps, in Upwelling Systems: Evolution Since the Early Miocene, edited by C. P. Summerhayes, W. L. Prell, and K. C. Emeis, Geol. Soc. Spec. Publ. London, 64, 93-106, 1992.

Delhairs, F., C. E. Lambert, R. Chesselet, and N. Risler, The biological production of marine suspended barite and the barium cycle in the western Mediterranean Sea, Biogeochemistry, 4, 119-139, 1987.

De Lange, G. J., and H. L. Ten Haven, Recent sapropel formation in the eastern Mediterranean, Nature, 305, 797-798, 1983.

Demaster, D. J., The supply and accumulation of silica in the marine environment, Geochim. Cosmochim. Acta, 45, 17151732, 1981.

De Visser, J. P., J. H. J. Ebbing, L. Gudjonsson, F. J. Hilgen, F. J. Jorissen, P. J. J. M. Verhallen, and D. Zevenboom, The origin or rhytmic bedding in the Pliocene Trubi formation of Sicily, southem Italy, Palaeogeogr. Palaeoclimarol. Palaeoecol., 69, 45-66, 1989.

Dymond, J., E. Suess, and M. Lyle, Barium in deep-sea sediment: A geochemical proxy for paleoproductivity, Paleoceanography, 7, 163-182, 1992.

Emeis, K. C., A. Camerlenghi, J. A. McKenzie, D. Rio, and R. Sprovieri, The occurrence and significance of Pleistocene and upper Pliocene sapropels in the Tyrrhenian Sea, Mar. Geol., 100, 155-182, 1991.

Emerson, S. R., and D. Archer, Calcium carbonate preservation in the ocean, Philos. Trans. R. Soc. London A, 331, 29-41, 1990.

Erba, E., Deep mid-water bacterial mats from anoxic basins of the eastern Mediterranean, Mar: Geol., 100, 83-102, 1991.

Fleming, R. H., General features of the ocean, in Treatise on Marine Ecology and Paleoecology, edited by J. W. Hedgpeth, Mem. Geol. Soc. Am., 67, 87-107, 1957.

Fontugne, M. R., and S. E. Calvert, Late Pleistocene variability of the carbon isotopic composition of organic matter in the eastern Mediterranean: Monitor changes in carbon sources and atmospheric $\mathrm{CO}_{2}$ concentrations, Paleoceanography, 7, 1-20, 1992.

Gascard, J. C., Mediterranean deep water formation, baroclinic instability and oceanic eddies, Oceanol. Acta, 1, 315-330, 1978.

Glaçon, G., C. Vergnaud-Grazzini, and M. J. Sigal, Premiers resultats d'une serie d'observations saisonnieres des foraminiferes du plancton Mediterraneen, in Plankıonic Conference Proceedings, vol. 2, edited by A. Farinacci, and R. Matteacci, pp. 555-574, Edizioni Tecnoscienza, Roma, Italy, 1971.

Goldberg, E. D., and G. O. S. Arthenius, Chemistry of Pacific pelagic sediments, Geochim. Cosmochim. Acta, 13, 153-212, 1958.

Gran, H. H., On the conditions for the production of plankton in the sea, Rapp. P. -v. Réun. Cons. Int. Explor: Mer. 75, 37-46, 1931.

Gudjonsson, L., Local and global effects on the Early Pliocene Mediterranean stable isotope records, Mar. Micropaleontol., 12, 241-253, 1987.

Gudjonsson, L., and G. J. van der Zwaan, Anoxic events in the Pliocene Mediterranean: Stable istope evidence for run-off, Proc. K. Ned. Akad. Wet., B, 88, 69-82, 1985.

Hay, W. W., and J. C. Brock, Temporal variation in intensity of upwelling off southwest Africa, in Upwelling Systems: Evolution Since the Early Miocene, edited by C. P. Summerhayes, W. L. Prell, and K. C. Emeis, Geol. Soc. Spec. Publ. London, 64, 463-498, 1992.

Hilgen, F. J., Sedimentary rhythms and high-resolution chronostratigraphic correlations in the Mediterranean Pliocene, Newsl. Stratigr., 17, 109-127, 1987.

Hilgen, F. J., Astronomical calibration of Gauss to Matuyama sapropels in the Mediterranean and implication for the geomagnetic polarity time scale, Earth Planet. Sci. Lett., 104, 226-244, 1991 a.

Hilgen, F. J., Extension of the astronomically calibrated (polarity) time scale to the Miocene/Pliocene boundary, Earth Planet. Sci. Lett., 107, 349-368, 1991 b.

Howell, M. W., R. Thunell, E. Tappa, D. Rio, and R. Sprovieri R., Late neogene laminated and opal-rich facies from the Mediterranean region: Geochemical evidence for mechanisms of formation, Palaeogeogr. Palaeoclimatol. Palaeoecol., 64, 265-286, 1988.

Howell, M. W., D. Rico, and R. C. Thunell, Laminated sediments from the Vrica Section (Calabria, D. Italy): Evidence for PlioPleistocene climatic change in the Mediterranean region, Palaeogeogr. Palaeoclimatol. Palaeoecol., 78, 195-216, 1990.

Hurd, D. E., Interactions of biogenic opal, sediment and seawater in central equatorial Pacific, Geochim. Cosmochim. Acta, 37, 2257-2282, 1973.

Jasper, J. P., and R. B. Gagosian, The sources and deposition of organic matter in the Late Quatemary Pigmy Basin, Gulf of Mexico, Geochin. Cosmochim. Acta, 54, 1117-1132, 1990.

Jonkers, H. A., Pliocene benthonic foraminifera from homogeneous and laminated marls on Crete, Utrecht Micropaleontol. Bull., 31, 179 pp, 1984.

Kennett, J. P., and M. S. Stinivasan, Neogene Planklonic Foraminifera, 263 pp., Hutchinson Ross, Stroudsburg, Pennsylvania, 1983.

Kidd, R. B., M. B. Cita, and W. B. F. Ryan, Stratigraplyy of eastern Mediterranean sapropel sequences recovered during leg 42A and their paleoenvironmental significance, Initial Rep. Deep Sea Drill. Proj., 42A, 412-443, 1978.

Killworth, P. D., The mixing and spreading phases of Medoc I, Prog. Oceanogr., 7, 59-90, 1976.

Klinklhammer, G. P., and C. E. Lambert. Preservation of organic matter during salinity excursions, Nature, 339, 271-274, 1989.

Koblents-Mishke, O. I., V. V. Volkoviusky, and Y. G. Kabanova, Plankton primary production of the World Ocean, in Scientific Exploration of the South Pacific, edited by W. Wooster, pp. 183-193, National Academy of Sciences, Washington, D. C., 1970.

Lea, D. W., and A. Boyle, Foraminiferal reconstruction of barium distributions in water masses of the glacial oceans, Paleoceanography, 5, 719-742, 1990.

Lohmann, G. P., and J. J. Carlson, Oceanographic significance of Pacific late Miocene calcareous nannoplankton, Mar. Micropaleontol., 6, 553-579, 1981.

Loubere, P., and K. Moss, Late Pliocene climatic clange and the onset of northern hemisphere glaciation as recorded in the northeast Atlantic Ocean, Geol. Soc. Am. Bull., 77, 818-828, 1986.

Lourens, L. J., F. J. Hilgen, L. Gudjonsson, and W. J. Zachariasse, Late Pliocene to early Pleistocene astronomically forced surface productivity and temperature variations in the Mediterranean, Mar. Micropaleontol., 19, 49-78, 1992.

Mann, K. H., and J. R. N. Lazier, Dynamics of Marine Ecosystems: Biological-Physical Interactions in the Oceans, $466 \mathrm{pp}$., Blackwell Scientific, Boston, Mass., 1991.

McKenzie, J. A., Pluvial conditions in the eastern Sahara following the penultimate deglaciation: Implications for changes in atmospheric circulation pattems with global warming, Palaeogeogr. Palaeoclimatol. Palaeoecol., 103, 95$105,1993$. 
Medoc Group, Observation of formation of deep water in the Mediterranean Sea, 1969, Nature, 227, 1037-1040, 1970.

Mitchell-Innes, B. A., and A. Winter, Coccolithophores: A major phytoplankton component in mature upwelled waters off the Cape Peninsula, South Africa in March, Mar: Biol., 95, 25-30, 1987.

Morel, A., and J. André, Pigment distribution and primary production in the western Mediterranean as derived and modeled from coastal zone color scanner observations, $J$. Geoph. Res., 96, 12,685-12,698, 1991.

Morse, J. W., and F. T. Mackenzie, Geochemistry of Sedimentary Carbonates, vol 48, Developments in Sedimentology, 707 pp., Elsevier, New York, 1990.

Múller, P. J., and E. Suess, Productivity, sedimentation rate, and sedimentary organic matter in the oceans, I, Organic carbon preservation, Deep-Sea Res., 26, 1347-1362, 1979.

Murray, D. W., and W. L. Prell, Pliocene and Pleistocene climatic oscillations and monsoon upwelling recorded in sediments from the Owen Ridge, northwestern Arabian Sea, in Upwelling Systems: Evolution Since the Early Miocene, edited by C. P. Summerhayes, W. L. Prell, and K. C. Emeis, Geol. Soc. Spec. Publ. London, 64, 310-320, 1992.

Nolet, G. J., and B. H. Corliss, Benthic foraminiferal evidence for reduced deep-water circulation during sapropel formation in the eastern Mediterranean, Mar. Geol., 94, 109-130, 1990.

Olausson, E., Studies of deep-sea cores, Rep. Swed. Deep Sea Exped. 1947-1948, 8, 353-391, 1961.

Ortiz, J. D., and A. C. Mix, The spatial distribution and seasonal succession of planktonic foraminifera in the California Current of Oregan, September 1987-September 1988, in Upwelling Systems: Evolution Since the Early Miocene, edited by C. P. Summerhayes, W. L. Prell, and K. C. Emeis, Geol. Soc. Spec. Publ. London, 64, 197-214, 1992.

Prell, W. L., and J. E. Kutzbach, Monsoon variability over the past 150,000 years, J. Geophys. Res., 92, 8411-8425, 1987.

Pruysers, P. A., G. J. De Lange, J. J. Middelburg, and D. J. Hydes, The diagenetic formation of metal-rich layers in sapropel-containing sediments in the eastern Mediterranean, Geochim. Cosmochim. Acta, 57, 527-536, 1993.

Rio, D., R. Sprovieri, and R. C. Thunell, Pliocene-lower Pleistocene chronostratigraphy: A reevaluation of Mediterranean type-sections, Geol. Soc. Am. Bull., 103, 1049-1058, 1991.

Rohling, E. J., and W. W. C. Gieskes, Late Quaternary changes in Mediterranean Intermediate Water density and formation rate, Paleoceanography, 5, 531-545, 1989.

Rohling, E. J., and F. J. Hilgen, The eastern Mediterranean climate at times of sapropel formation, Geol. Mijnborw, 70, 253-264, 1991.

Rossignol-Strick, M., African monsoons, an immediate climatic response to orbital insolation, Narure, 303, 46-49, 1983.

Rossignol-Strick, M., Mediterranean Quaternary sapropels, and immediate response of the African monsoon to variations of insolation, Palaeogeogr. Palaeoclimatol. Palaeoecol., 49, 237. 263, 1985.

Rossignol-Strick, M., Rainy periods and bottom water stagnation initiating brine accumulation and metal concentrations, 1 , The late Quaternary, Paleoceanography, 2, 333-360, 1987.

Rossignol-Strick, M., W. Nesteroff, P. Olive, and C. VergnaudGrazzini, After the deluge: Mediterranean stagnation and sapropel formation, Nature, 295, 105-110, 1982.

Sackett, W. M., The depositional history and isotopic organic carbon composition of marine sediments, Mar. Geol., 2, 173185, 1964.

Sarmiento, J. L., T. Herbert, and J. R. Toggweiler, Mediterranean nutrient balance and episodes of anoxia, Global Biogeocherll. Cycles, 2, 427-444, 1988.
Sarnthein, M., J. C. Duplessy, and M. R. Fontugne, Global variations of surface ocean productivity in low and mid latitudes: Influence on $\mathrm{CO}_{2}$ reservoirs of the deep ocean and atmosphere during the last 21,000 years, Paleoceanography, 3, 361-399, 1988.

Sarnthein, M., U. Pflaumann, R. Ross, R. Tiedemann, and K. Winn, Transfer functions to reconstruct ocean paleoproductivity: a comparison, in Upwelling Systems: Evolution Since the Early Miocene, edited by C. P. Summerhayes, W. L. Prell, and K. C. Emeis, Geol. Soc. Spec. Publ. London, 64, 411-427, 1992.

Schmitz, B., Barium, equatorial high productivity, and the northward wandering of the Indian continent, Paleoceanography, 2, 63-77, 1987.

Schrader, H., Peruvian coastal primary paleoproductivity during the last 200.000 years, in Upwelling Systems: Evolution Since the Early Miocene, edited by C. P. Summerhayes, W. L. Prell, and K. C. Emeis, Geol. Soc. Spec. Publ. London, 64, 391-410, 1992.

Schrader, H., and A. Matherne, Sapropel formation in the eastern Mediterranean Sea: Evidence from preserved opal assemblages, Mar: Micropaleontol., 27, 191-203, 1981.

Shaw, H. F., and G. Evans, The nature, distribution and origin of a sapropelic layer in sediments of the cilicia basin, northeastern Mediterranean, Mar. Geol., 61, 1-12, 1984.

Shimmield, G. B., N. B. Price, and T. F. Pedersen, The influence of hydrography, bathymetry, and productivity on sediment type and composition from the Oman margin and the Northwest Arabian Sea, in The Geology and Tectonics of the Oman Region, edited by A. H. F. Robertson, M. P. Searle, and A. C. Ries, Spec. Publ. Geol. Soc. All., 49, 761-771, 1990.

Sprovieri, R., R. C. Thunell, and M. W. Howell, Paleontological and geochemical analyses of three laminated sedimentary units of late Pliocene-early Pleistocene age from the Monte San Nicola section in Sicily, Riv. Ital. Paleontol, 92, 401-434, 1986.

Stumm, W., and J. J. Morgan. Aquatic Chemistry, 780 pp., Jolın Wiley, New York, 1981.

Tang, C. M., and L. D. Stott, Seasonal salinity changes during Mediterranean sapropel deposition 9000 years B.P.: Evidence from isotopic analyses of individual planktonic foraminifera, Paleoceanography, 8, 473-493, 1993.

Thomson, J., N. C. Higgs, I. W. Croudace, S. Colley, and D. J. Hydes, Redox zonation of elements at an oxic/postoxic boundary in deep-sea sediments, Geochim. Cosmochim. Acta, 57, 579-595, 1993.

Thunell, R. C., Distribution of recent planktonic foraminifera in surface sediments of the Mediterranean Sea, Mar. Micropaleontol., 3, 147-173, 1978.

Thunell, R. C., and D. F. Williams, Glacial-Holocene salinity changes in the Mediterranean Sea: Hydrograplic and depositional effects, Nature, 338, 493-496, 1989.

Thunell, R. C., D. Rio, R. Sprovieri, and I. Raffi, Limestone-marl couplets: origin of the early Pliocene Trubi marls in Calabria, Southern Italy, J. Sediment. Petrol., 61, 1109-1122, 1991.

Tolderlund, D. S., and A. W. H. BE, Seasonal distibution of planktonic foraminifera in the western North Atlantic, Micropaleontology, 17, 297-329, 1971.

Van der Weijden, C. H., Geochemistry of the Semaforo (Stuni) and Vrica sections (Calabria, Italy), Palaeogeogr. Palaeoclimatol. Palaeoecol., 103, 203-221, 1993.

Van Os, B. J. H., J. J. Middelburg. and G. J. De Lange, Possible diagenetic mobilization of barium in sapropelic sediment from the eastern Mediterranean, Mar: Geol., 100, 125-136, 1991.

Van Os, B. J. H., and E. J. Rolling, Oxygen isolope depletions in eastern Mediterranean sapropels exclude estuarine cir- 
culation, in Primary and diagenetic signals in the Mediterranean sapropels and North Atlantic turbidites, edited by B. J. H. Van Os, Geol. Ultraiectina, 109, 3-12, 1993.

Van Os, B. J. H., J. J. Middelburg, and G. J. De Lange, Extensive remineralization and fractionation of organic matter during weathering, in Primary and diagenetic signals in the Mediterranean sapropels and Nortl Atlantic turbidites, edited by B. J. H. Van Os, Geol. Ultraiectina, 109, 85-95, 1993.

Vergnaud-Grazzini, C., and C. Pierre, High fertility in the Alboran Sea since the last glacial maximum, Paleoceanography, 6, 519-536, 1991.

Vergnaud-Grazzini, C., W. B. F. Ryan, and M. B. Cita, Stable isotope fractionation, climatic change and episodic stagnation in the eastern Mediterranean during the late Quaternary, Mar. Micropaleontol., 2, 353-370, 1977.

Welling, L. A., N. G. Pisias, and A. K. Roelofs, Radiolarian microfauna in the northern California Current System: indicators for multiple processes controlling productivity, in Upwelling Systems: Evolution Since the Early Miocene, edited by C. P. Summerhayes, W. L. Prell, and K. C. Emeis, Geol. Soc. Spec. Publ. London, 64, 177-196, 1992.

Wijmstra, T. A., R. Young, and H. J. L. Witte, An evolution of the climatic conditions during the late Quaternary in northern Greece by means of multivariate analysis of palynological data and comparison with recent phytosociological and climatic data, Geol. Mijnbouw, 9, 243-251, 1990.

Williams, D. F., R. C. Thunell, and J. P. Kennett, Periodic freshwater flooding and stagnation of the eastern Mediterranean Sea during the late Quaternary, Science, 201, 252-254, 1978.
Wooster, W. S., A. Bakun, and D. R. McLain, The seasonal upwelling cycle along the eastern boundary of the North Atlantic, J. Mar: Res., 34, 131-141, 1976.

Zachariasse, W. J., L. Gudjonsson, F. J. Hilgen, C. G. Langereis, L. J. Lourens, P. J. J. M. Verhallen, and J. D. A. Zijderveld Late Gauss to early Matuyama invasions of Neogloboquadrina atlantica in the Mediteranean and associated record of climatic change, Paleoceanography, 5, 239-252, 1990.

Zijderveld, J. D. A., C. G. Langereis, F. J. Hilgen, P. J. J. M. Verhallen, and $\mathrm{W}$. J. Zachariasse, Integrated magnetostratigraphy and biostratigraphy of the upper Pliocenelower Pleistocene from the Monte Singa and Crotone areas in southern Calabria (Italy), Earth Planet. Sci. Lett., 107, 697 $714,1991$.

L. Beaufort, Laboratorie de Geologie du Quaternaire, Centre National de la Recherche Scientifique, Case 907. Luminy, 13288 Marseille Cedex 9, France.

F. J. Hilgen, G. J. De Lange, L. J. Lourens, and B. J. Van Os, Department of Geochemistry and Geology, Institute of Earth Sciences, University of Utrecht, Budapestlaan 4, P.O. Box 80.021, 3508 TA Utrecht. The Netherlands. (e-mail: bertil@escher.earth.ruu.nl)

(Received September 27, 1993; revised February 22, 1994; accepted February 24, 1994.) 